\title{
Identification and quantification of particulate tracers of exhaust and non-exhaust vehicle emissions
}

\author{
Aurélie Charron $^{1,2}$, Lucie Polo-Rehn ${ }^{1,2}$, Jean-Luc Besombes ${ }^{3}$, Benjamin Golly ${ }^{3}$ Christine Buisson $^{4}$, Hervé Chanut ${ }^{5}$, \\ Nicolas Marchand $^{6}$, Géraldine Guillaud ${ }^{5}$, and Jean-Luc Jaffrezo ${ }^{1}$ \\ ${ }^{1}$ Université Grenoble Alpes, CNRS, IRD, IGE (UMR 5001), 38000 Grenoble, France \\ ${ }^{2}$ IFSTTAR, 69675 Bron, France \\ ${ }^{3}$ LCME, Université Savoie Mont Blanc, LCME, 73000 Chambéry, France \\ ${ }^{4}$ LICIT, ENTPE, IFSTTAR, 69518 Vaux en Velin, France \\ ${ }^{5}$ Atmo Auvergne-Rhône-Alpes, 69500 Bron, France \\ ${ }^{6}$ Aix-Marseille Université, CNRS, LCE, 13331 Marseille, France
}

Correspondence: Aurélie Charron (aurelie.charron@univ-grenoble-alpes.fr)

Received: 7 August 2018 - Discussion started: 1 October 2018

Revised: 28 January 2019 - Accepted: 19 February 2019 - Published: 17 April 2019

\begin{abstract}
In order to identify and quantify key species associated with non-exhaust emissions and exhaust vehicular emissions, a large comprehensive dataset of particulate species has been obtained thanks to simultaneous nearroad and urban background measurements coupled with detailed traffic counts and chassis dynamometer measurements of exhaust emissions of a few in-use vehicles wellrepresented in the French fleet. Elemental carbon, brakewear metals (Cu, Fe, Sb, Sn, Mn), n-alkanes (C19-C26), light-molecular-weight polycyclic aromatic hydrocarbons (PAHs; pyrene, fluoranthene, anthracene) and two hopanes ( $17 \alpha 21 \beta$ norhopane and $17 \alpha 21 \beta$ hopane) are strongly associated with the road traffic. Traffic-fleet emission factors have been determined for all of them and are consistent with most recent published equivalent data. When possible, lightduty- and heavy-duty-traffic emission factors are also determined. In the absence of significant non-combustion emissions, light-duty-traffic emissions are in good agreement with emissions from chassis dynamometer measurements. Since recent measurements in Europe including those from this study are consistent, ratios involving copper $(\mathrm{Cu} / \mathrm{Fe}$ and $\mathrm{Cu} / \mathrm{Sn}$ ) could be used as brake-wear emissions tracers as long as brakes with $\mathrm{Cu}$ remain in use. Near the Grenoble ring road, where the traffic was largely dominated by diesel vehicles in $2011(70 \%)$, the OC/EC ratio estimated for traffic emissions was around 0.4. Although the use of quantitative data for source apportionment studies is not straightforward
\end{abstract}

for the identified organic molecular markers, their presence seems to well-characterize fresh traffic emissions.

\section{Introduction}

Traffic is a major source of particulate matter in urban environments through both exhaust and non-exhaust emissions. Thanks to stringent regulations, vehicles with more efficient catalytic converters and diesel particle filters have been progressively introduced into the European fleet. As a consequence particulate exhaust emissions have strongly decreased and non-exhaust particulate emissions (particles resuspended by moving traffic and those from the wear of brakes, tyres, road surface, etc.) will contribute to the major part of particulate vehicular emissions in the near future (Amato et al., 2014). Current research estimates that nonexhaust emissions already substantially contribute to traffic emissions, with differences between sites due to local meteorology, local emissions or traffic characteristics (e.g. Omstedt et al., 2005; Thorpe and Harrison, 2008; Bukowiecki et al., 2009; Lawrence et al., 2016). Even with electric vehicles, traffic will continue to be a source of particulate matter (PM) through non-exhaust emissions (Pant and Harrison, 2013; Timmers and Achten, 2016).

Also, knowledge on the deleterious impacts of PM from vehicular emissions on human health is increasing. There is 
now strong evidence that traffic-related PM is responsible for adverse health effects due to the health effect of both carbonaceous material from exhaust emissions and redox-active metals in traffic-generated dust including road, brake and tyre wear (Kukutschová et al., 2009; Cassee et al., 2013; Amato et al., 2014, and references therein; Pardo et al., 2015; Poprac et al., 2017). Recently, on the one hand, Shirmohammadi et al. (2017) and Weber et al. (2018) have shown the important role of non-tailpipe emissions in the oxidative potential of particulate matter species identified as tracers of vehicle abrasion; and, on the other hand, the health impacts of coarse particles is now better documented (Beelen et al., 2014; Cheng et al., 2015; Malig et al., 2013). Therefore, a better knowledge on vehicular emissions is required to better understand their contribution to urban atmospheric $\mathrm{PM}_{10}$ concentration levels and related health effects.

Chassis dynamometer measurements allow the determination of exhaust vehicular emissions under controlled testing conditions, but, because of high costs, these tests often include small sets of vehicles that cannot be representative of large variation in engine type, age and maintenance history. They also do not represent the variability in driving types in various environments. All of these are parameters that strongly influence real-world vehicular emissions. Additionally, these tests cannot simulate accurately the effect of dilution on particle equilibrium in the road atmosphere (Kim et al., 2016), the possible rapid-aging effects (e.g. Platt et al., 2017) and non-tailpipe emissions (e.g. Thorpe and Harrison, 2008). For all these reasons, it is thought that more realistic estimates of vehicle emissions are determined from air quality measurements in the near-road atmosphere (Phuleria et al., 2017), including car-chasing, tunnel or roadside measurements (Pant and Harrison, 2013, and references therein; Jezek et al., 2015).

In this study, a large comprehensive dataset on the chemical composition of $\mathrm{PM}_{10}$ from exhaust and non-exhaust emissions has been obtained thanks to two complementary campaigns: (1) simultaneous near-road and urban background measurements coupled with detailed traffic counts for the estimation of real-world vehicular emissions including non-exhaust emissions and (2) chassis dynamometer measurements of exhaust emissions of a few in-use vehicles wellrepresented in the French fleet for the identification of key species in exhaust emissions. This study focuses on $\mathrm{PM}_{10}$ in order to take into account the entire breathable fraction of non-exhaust particulate emissions, a large part of which are coarse particles (Thorpe and Harrison, 2008; Grigoratos and Martini, 2015). Possible particulate tracers of exhaust and non-exhaust vehicle emissions are examined and quantified. Emission factors and, when possible, typical ratios, are derived from these data.

\section{Methodology}

\subsection{Chassis dynamometer measurements}

Vehicles were operated on a chassis dynamometer, and exhaust emissions were measured using a sampling train including a constant volume sampling (CVS) system in which emissions are diluted with filtered air and sampled using quartz filters and polyurethane foams (PUF).

\subsubsection{Vehicle types and driving cycles}

Five vehicles representative of the most frequent vehicle classes in the French fleet in circulation were selected (Euro 3 diesel, Euro 4 diesel, Euro 4 diesel retrofitted with a particle filter, Euro 2 petrol, Euro 4 petrol). They were in-use private cars since rental vehicles may not be representative of the national fleet (low mileage). All vehicles were operated using commercial diesel and petrol fuels. Selection criteria and characteristics of tested vehicles are described in the Supplement.

Driving cycles designed to be representative of real driving conditions in Europe are performed in this study (André, 2004). The ARTEMIS urban cycle represents driving conditions in urban areas (repeated acceleration and vehicle speed below $40 \mathrm{~km} \mathrm{~h}^{-1}$ ), while the ARTEMIS rural-road cycle represents driving conditions on main roads in suburban and rural areas outside cities (flowing traffic conditions). These cycles represent most driving conditions encountered on the RN87/E712 highway, where the roadside experiments took place, during congested and flowing traffic conditions, respectively. Since urban journeys include cold vehicles, the influence of the cold start on urban emissions has been systematically tested.

\subsubsection{Exhaust sampling}

Vehicles were operated on a chassis dynamometer using a CVS system to dilute exhaust emissions with filtered ambient air. The filtration system included four filters and a cartridge in series: M6-F7-F9, M5, F7 EN-779-2012 filters; a HEPA H13 EN1822-2009 filter; and a cylindrical cartridge of charcoal scrubber.

Regulated emissions were determined with continuous monitors for $\mathrm{CO}, \mathrm{CO}_{2}, \mathrm{NO}_{x}$ and total hydrocarbons (HORIBA system). Particulate matter and volatile organic compounds (VOC) were sampled out from the dilution tunnel with a servo-controlled system designed by Serv'Instrumentation for this study. Two driving cycles in series were performed in order to collect enough matter for molecular speciation. PM was collected on quartz filters (Tissuquartz ${ }^{\mathrm{TM}}$, diameter $47 \mathrm{~mm}$ ), at flow rates depending on both the emission levels of the vehicles being tested and the types of analyses (from 5 to $50 \mathrm{~L} \mathrm{~min}^{-1}$ for EC/OC measurements and from 30 to $50 \mathrm{~L} \mathrm{~min}^{-1}$ for organic molecular speciation). Dilution factors ranged from about 15 to 
40. Conditions of vehicle tests are detailed in the Supplement (Table S2). Filter face velocities for chassis dynamometer samplings dedicated to organic speciation were similar or close to the one of atmospheric near-road measurements, while, because of very high concentration levels, lower sample flow rates are used for PM samplings dedicated to EC and OC measurements in the exhaust of diesel vehicles nonretrofitted with a particulate filter (Euro 3 and Euro 4 diesel vehicles). These very low filter velocities may influence the adsorption of organic vapours by the quartz filter (McDow and Huntzicker, 1990; Turpin et al., 2000; Vecchi et al., 2009), while EC would not be affected by filter face velocity (Vecchi et al., 2009). Quartz filters were pre-baked at $500^{\circ} \mathrm{C}$ for $8 \mathrm{~h}$ before being used. Samples were stored at $-18^{\circ} \mathrm{C}$ in aluminum foil and sealed in polyethylene bags until analyses.

Analysis of test blank filters (collected following the same procedure as vehicle test filters including driving cycle durations with filtered air) showed contaminations from the CVS system. It was obvious that some organic compounds measured in test blanks result from the desorption of semivolatile organics deposited into the CVS, which is favoured by cleaner air. Since blank levels decreased in time with passing air dilution through the system, our procedure included such a step maintained for a duration corresponding to at least two driving cycles before each vehicle test. Test blanks are used to correct measurements.

\subsection{Near-road and urban background measurements}

The joint PM-DRIVE (Particulate Matter Direct and Indirect on-road Vehicular Emissions) and MOCOPO (Measuring and mOdelling traffic COngestion and POllution) field campaign took place from 9 to 23 September, 2011. It included meteorology and traffic measurements, near-road and urban background $\mathrm{PM}_{10}$ sampling (this study), and near-road online measurements (discussed in DeWitt et al., 2015).

\subsubsection{Description of traffic and urban background sites}

The Grenoble conurbation is a large city with about 700000 inhabitants. It is located in the southeast of France in the French Alps and is surrounded by three mountain ranges (Vercors, Chartreuse, and Belledonne). The traffic site was located $\left(45.150641^{\circ} \mathrm{N}, 5.726028^{\circ} \mathrm{E}\right)$ about $15 \mathrm{~m}$ away from the southern part of the Grenoble ring road (the RN87/E712 highway with $2 \times 2$ lanes) ( $26 \mathrm{~m}$ from the roadway central axis). Total traffic flow for the four lanes was on average 95000 and 65000 vehicles a day on workdays and weekend, respectively, with frequent congestion during extended commuting hours. Stop-and-go traffic in both directions generates large braking activity at that time. This sampling site was highly equipped during the joint PMDRIVE-MOCOPO field campaign. Simultaneous measurements took place at an urban background site (Les Frênes) which is located about $2 \mathrm{~km}$ away from the traffic site, on the rooftop of a school. This site belongs to the regional air pollution network managed by Atmo Auvergne-RhôneAlpes (http://www.atmo-auvergnerhonealpes.fr/, last access: March 2019). The locations of both sites are presented on Fig. 1.

\subsubsection{Aerosol and gas measurements}

On both traffic and urban background sites, $\mathrm{PM}_{10} \mathrm{HiVol}$ (DA80, $30 \mathrm{~m}^{3} \mathrm{~h}^{-1}$ ) samplers collected $\mathrm{PM}_{10}$ on quartz fibre filters (Tissuquartz ${ }^{\mathrm{TM}}$, diameter $150 \mathrm{~mm}$ ) with a time resolution of $4 \mathrm{~h}$. Filters were preheated at $500^{\circ} \mathrm{C}$ during $3 \mathrm{~h}$. After sampling, filters were individually placed in aluminum foil, sealed in polyethylene bags and stored at $-18^{\circ} \mathrm{C}$ until analysis. In addition, both sites were equipped with $\mathrm{NO}_{x}(\mathrm{NO}$ and $\mathrm{NO}_{2}$ ) and $\mathrm{CO}$ monitors. $\mathrm{PM}_{10}$ and $\mathrm{PM}_{2.5}$ mass concentrations were also continuously measured using an $8500 \mathrm{C}$ series TEOM-FDMS (Filter Dynamics Measurement System and tapered element oscillating microbalance mass sensor housed in a single-cabinet compact enclosure).

\subsubsection{Traffic measurements}

Traffic counters (double electromagnetic loops) were installed in order to identify the passing of all vehicles, the length of their chassis and their speeds, the determination of the two vehicle classes used in this study (light-duty and heavy-duty vehicles, or LDVs and HDVs), and the identification of periods of stop-and-go or flowing traffic. Vehicle mean speeds are computed as the harmonic mean speed of the cars passing over the detector (flow speed, i.e. the spatial mean speed) (Hall, 2001).

Traffic cameras mounted on a roadway gantry were also used to monitor traffic at the measurement site. They were used to capture the license plate numbers of passing vehicles. Plate numbers were later used to classify vehicular traffic into different categories: Euro standards and fuel type (diesel or petrol). The traffic of the highway is detailed elsewhere (DeWitt et al., 2015; Fallah Shorshani et al., 2015). On weekdays, the average hourly traffic included 2850 diesel vehicles (including about 200 heavy-duty vehicles) and 1025 petrol vehicles. The harmonic vehicle mean speed was about $80 \mathrm{~km} \mathrm{~h}^{-1}$ and ranged from 52 to $94 \mathrm{~km} \mathrm{~h}^{-1}$ (note that the RN87 highway has a speed limit of $90 \mathrm{~km} \mathrm{~h}^{-1}$ ). A sample is considered affected by congested traffic above a threshold of more 22000 vehicles during the $4 \mathrm{~h}$ sampling periods (corresponding to vehicle speed below $70 \mathrm{~km} \mathrm{~h}^{-1}$ ) (see Supplement). However, braking may occur below this threshold for congestion.

The vehicle fleet was close to the national one for the year 2011, with $72 \%$ diesel vehicles and Euro 3 and 4 vehicles representing most of the vehicles $30 \%$ and $36 \%$, respectively). Virtually all heavy-duty vehicles are diesel. 


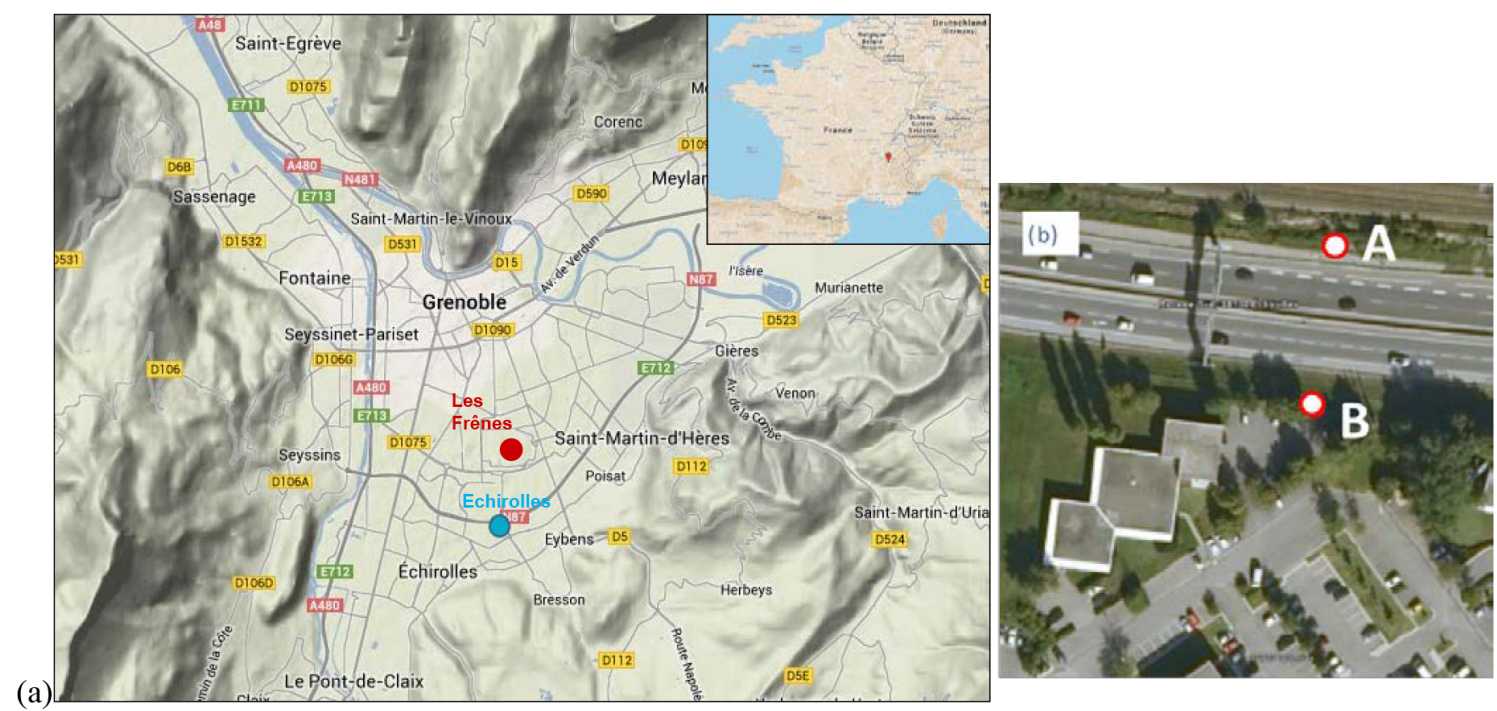

Figure 1. (a) Location of sampling sites in the Grenoble Alpes conurbation: the roadside site (Echirolles) and the urban background site (Les Frênes). (b) Echirolles sampling site: sampling and measurement devices are around the B point; the traffic electromagnetic loop monitoring is beneath the road (on the $\mathrm{AB}$ line), on the left; and the cameras linked to automatic license plate recognition code are located on overhead gantries.

\subsubsection{Meteorological measurements}

A Young meteorological station was installed at the traffic site to capture wind speed and direction, while relative humidity, temperature data and rain data are obtained from two stations located in the Grenoble conurbation (see Supplement Sect. IV).

The wind speed was low during the field campaign (on average $0.98 \mathrm{~m} \mathrm{~s}^{-1}$, ranging from 0.50 to $2.5 \mathrm{~m} \mathrm{~s}^{-1}$ ). The temperature was warm (on average $17.6^{\circ} \mathrm{C}$, peaked to $27^{\circ} \mathrm{C}$ ) and was higher before the first rain event (on Sunday 17 September 2011) with average temperatures of 21 and $15^{\circ} \mathrm{C}$, respectively, before and after the rain event. Two rain events occurred during the campaign: the first one from the morning of 17 September 2011 to the night of 18 September 2011 (34 $\mathrm{mm}$ of rain) and the second one from the night of 18 September to the afternoon of 19 September 2011 $(12.7 \mathrm{~mm})$. They corresponded to summer storms.

\subsection{Chemical analyses}

The measurements of carbonaceous material (EC and OC) in PM samples were performed using the thermo-optical transmission (TOT) method on a Sunset Lab analyser (Jaffrezo et al., 2005; Aymoz et al., 2006) following the EUSAAR2 temperature protocol (Cavalli et al., 2010). Ionic species were analysed with ionic chromatography (IC) following a well-established method (Jaffrezo et al., 1998; Waked et al., 2014). Metals were analysed using inductively coupled plasma mass spectrometry (ICP-MS) (Waked et al., 2014). The chemical speciation of organic particles is performed by gas chromatography-mass spectrometry (GC-MS), ex- cept for PAHs that were measured by liquid chromatography (HPLC) using a fluorescence detector (Piot, 2011; Golly et al., 2015).

Hence, a large number of particulate chemical species have been measured in the filter samples simultaneously collected at the traffic and urban background sites, including $\mathrm{EC}, \mathrm{OC}, 9$ major ions $\left(\mathrm{Cl}^{-}, \mathrm{NO}_{3}^{-}, \mathrm{SO}_{4}^{2-}\right.$, oxalate, $\left.\mathrm{Na}^{+}, \mathrm{NH}_{4}^{+}, \mathrm{K}^{+}, \mathrm{Mg}^{2+}, \mathrm{Ca}^{2+}\right), 33$ metals and trace elements ( $\mathrm{Al}, \mathrm{As}, \mathrm{Ba}, \mathrm{Ca}, \mathrm{Cd}, \mathrm{Ce}, \mathrm{Co}, \mathrm{Cr}, \mathrm{Cs}, \mathrm{Cu}, \mathrm{Fe}$, $\mathrm{K}, \mathrm{La}, \mathrm{Li}, \mathrm{Mg}, \mathrm{Mn}, \mathrm{Mo}, \mathrm{Na}, \mathrm{Ni}, \mathrm{Pb}, \mathrm{Pd}, \mathrm{Pt}, \mathrm{Rb}, \mathrm{Sb}$, $\mathrm{Sc}, \mathrm{Se}, \mathrm{Sn}, \mathrm{Sr}, \mathrm{Ti}, \mathrm{Tl}, \mathrm{V}, \mathrm{Zn}, \mathrm{Zr}$ ), 3 sugars (galactosan, mannosan, levoglucosan), 15 PAHs (phenanthrene, anthracene, fluoranthene, pyrene, retene, benzo(a)anthracene, chrysene, benzo(e)pyrene, benzo(b)fluoranthene, benzo(k)fluoranthene, benzo(a)pyrene, benzo(ghi)perylene, dibenzo(a,h)anthracene, indeno(1,2,3-cd)pyrene, coronene), 30 n-alkanes (from $\mathrm{C} 10$ to $\mathrm{C} 40$ ), 2 branched alkanes (pristane and phytane) and 10 hopanes (trisnorneohopane, $\quad 17 \alpha$-trisnorneohopane, $\quad 17 \alpha 21 \beta$-norhopane, $17 \alpha 21 \beta$-hopane, $\quad 17 \alpha 21 \beta$-22S-homohopane, $\quad 17 \alpha 21 \beta$ 22R-homohopane, $17 \alpha 21 \beta$-22R-bishomohopane, $17 \alpha 21 \beta$ 22S-bishomohopane, 17 $\alpha 21 \beta$-22S-trishomohopane, and $17 \alpha 21 \beta$-22R-trishomohopane).

The same array of chemical species were also quantified in the filter samples from the chassis dynamometer experiments.

\subsection{Data analysis}

A series of multivariate data analysis tools have been used in order to define which species are related to traffic, to identify influential parameters and to quantify their respective 
influences. Thanks to simultaneous measurements at neartraffic and background sites, local increments in concentration at the traffic site have been calculated as the difference between near-traffic and urban background concentrations. The sign and Wilcoxon signed-rank tests have been used to estimate if concentrations measured at the near-traffic site are significantly higher than concentrations measured at the urban background site and can possibly be ascribed to local traffic emissions. As a complementary indication of the relation to traffic, Spearman correlations with traffic data (total traffic, light-duty traffic, heavy-duty traffic), with $\mathrm{NO}_{x}$ (as an indicator of traffic emissions) and with EC (as an indicator of diesel traffic emissions) (Morawska and Zhang, 2002; Reche et al., 2011), have also been examined. Results for species for which concentrations are significantly higher at the near-traffic site (then including both positive increments and $p$ values below 0.05 from the sign and Wilcoxon signedrank tests) are presented in Table $1 \mathrm{a}$ and $\mathrm{b}$.

Increments in concentrations for all species strongly associated with traffic are transformed into emissions according to a well-established procedure (e.g. Pant and Harrison, 2013; Charron and Harrison, 2005; details in the Supplement Sect. V). This method enables the calculation of average emission factors for the mixed traffic fleet of the RN87 highway assuming that (1) increments in concentration (near-traffic site minus urban traffic site) are from local traffic, (2) emissions of $\mathrm{NO}_{x}$ are known and estimated from emission inventories (COPCETE, which uses emission functions from the European COPERT4 averaged for fleet composition and speed) and detailed traffic counts, and (3) atmospheric dilution affects all pollutants similarly. Average emission factors (EFs) are expressed in $\mathrm{mg} \mathrm{veh}^{-1} \mathrm{~km}^{-1}$ or $\mu \mathrm{g} \mathrm{veh}{ }^{-1} \mathrm{~km}^{-1}$ (Table 2a, b, c and d). Since it is thought that nearby industrial activities influence the concentrations of $\mathrm{Ti}$, $\mathrm{Cr}, \mathrm{Fe}$ and $\mathrm{Mn}$ in the morning, these data are excluded from the calculations. Standard multiple linear regression analyses (SPSS software) are performed between computed average emission data and light-duty and heavy-duty vehicle counts. The coefficients of the regressions represent average EFs for local heavy-duty and light-duty traffic (Table 3 ). The constants represent the parts not related to local traffic. They are all not significant ( $p$ values above 0.4 for metals and organics, $p$ value of 0.061 for EC), confirming the above assumption that mostly local traffic contributes to local increments in concentration. Results from multiple linear regressions are not available for all species strongly related to traffic, since its use requires normally distributed data and the model must be validated through residues analyses.

\section{Results}

Average concentrations measured at the traffic site are presented in the Supplement (Sect. II). Four-hour PM 10 concentrations ranged from 4.9 to $45.1 \mu^{-3} \mathrm{~m}^{-3}$ (on average

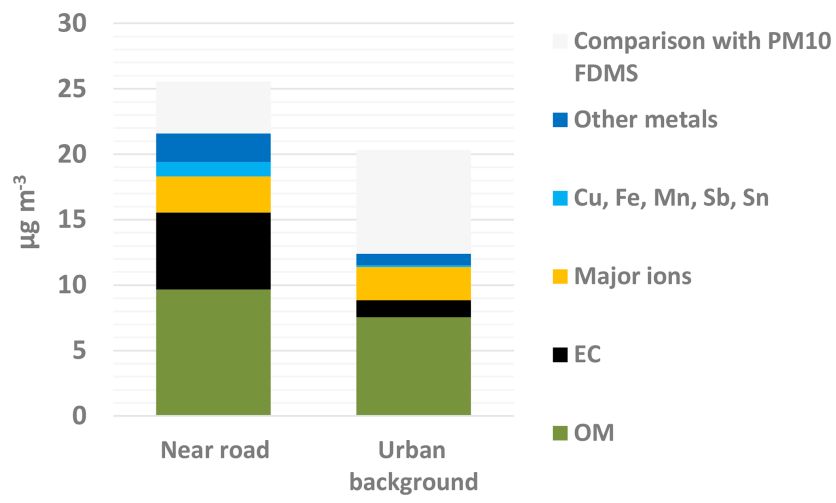

Figure 2. Median concentrations measured at the roadside site (Echirolles) and urban background site (Les Frênes) as well as comparison with respective median TEOM-FDMS $\mathrm{PM}_{10}$ concentrations. Organic matter $(\mathrm{OM})$ is computed using the factor 1.8 estimated for Grenoble city (Favez et al., 2010).

$24.1 \mu \mathrm{g} \mathrm{m}^{-3}$ ) and were strongly dominated by EC (on average $5.9 \mu \mathrm{g} \mathrm{m}^{-3}$ ) and OC (on average $5.4 \mu \mathrm{g} \mathrm{m}^{-3}$ ). At this site in the vicinity of traffic dominated by diesel vehicles, EC and OC concentrations were of similar magnitude. EC concentrations peaked at commuting time in the early morning and at the end of the afternoon, which follows quite well the evolution of traffic; the temporal evolution of OC is closer to that of sulfate with somewhat stronger variability following that of traffic. The other major constituents of $\mathrm{PM}_{10}$ were sulfate (on average $1.2 \mathrm{\mu g} \mathrm{m}^{-3}$ ), iron (on average $1.0 \mu \mathrm{g} \mathrm{m}^{-3}$ ) and calcium (on average $0.8 \mu \mathrm{g} \mathrm{m}^{-3}$ ). Strong showers during the weekend in the middle of the 2-week campaign led to $\mathrm{PM}_{10}$ concentrations below $10 \mu \mathrm{g} \mathrm{m}^{-3}$ during a few hours (see Fig. 3 and Supplement Sect. VII for individual particulate species).

\subsection{Identification of species related to local on-road traffic}

Table 1a and b present species for which concentrations are significantly higher at the near-traffic site and assumed from local emissions, and Fig. 2 presents median concentrations measured at both sites. These species could be distributed into two main groups according to both the significance of the contribution of traffic to atmospheric levels and the strength of relations with traffic indicators (traffic counts, $\mathrm{NO}_{x}$ and EC concentrations).

\subsubsection{Species strongly associated with local traffic}

$\mathrm{Cu}, \mathrm{Fe}, \mathrm{Mn}, \mathrm{Sb}$ and $\mathrm{Sn}$ have concentrations strongly correlated with traffic indicators (Table 1a). Their local increments in concentration due to traffic range from $54 \%$ to $84 \%$. The concentrations of these species are linearly related to each other with near-zero intercepts (Fig. 4), confirming that they come from the same source. Similarly to this study, Amato 
Table 1. (a) Median increments to concentrations measured near the RN87 highway in comparison to those measured in the urban background site (given in $\%$ of total concentrations) for species for which concentrations are significantly higher at the near-traffic site according to the sign and Wilcoxon signed-rank tests $(p<0.05)$. $\mathrm{PM}_{\text {coarse }}$ (difference between $\mathrm{PM}_{10}$ and $\left.\mathrm{PM}_{2.5}\right)$ is also included in this table. $R$ represents the Spearman correlation coefficients with traffic, heavy-duty traffic (HDV), nitrogen oxides $\left(\mathrm{NO}_{x}\right)$ and elemental carbon (EC). $N_{\mathrm{T}}$ is the number of samples collected at the traffic site (Echirolles), and $N_{\mathrm{UB}}$ is the number of samples collected at the urban background site (Les Frênes site). (b) Median increments to concentrations measured near the RN87 highway in comparison to the urban background site (given in $\%$ of total concentrations at the traffic site) for organic species for which concentrations are significantly higher at the traffic site according to the sign and Wilcoxon signed-rank tests $(p<0.05)$. $R$ represents the Spearman correlation coefficients with traffic, heavy-duty traffic (HDV), nitrogen oxides $\left(\mathrm{NO}_{x}\right)$ and elemental carbon (EC). $N_{\mathrm{T}}$ is the number of samples collected at the traffic site (Echirolles), and $N_{\mathrm{UB}}$ is the number of samples collected at the urban background site (Les Frênes site).

\begin{tabular}{|c|c|c|c|c|c|c|c|c|c|c|}
\hline Pollutant & $N_{\mathrm{T}}$ & $N_{\mathrm{UB}}$ & $\begin{array}{r}\text { Median } \\
\text { increment }(\%)\end{array}$ & $\begin{array}{l}\text { Sign test } \\
p \text { value }\end{array}$ & $\begin{array}{r}\text { Wilcoxon } \\
\text { signed-rank } \\
\text { test } p \text { value }\end{array}$ & $\begin{array}{r}R \text { with } \\
\text { total traffic }\end{array}$ & $\begin{array}{r}R \text { with } \\
\text { HDV }\end{array}$ & $\begin{array}{r}R \text { with } \\
\mathrm{NO}_{x}\end{array}$ & $\begin{array}{r}R \text { with } \\
\text { EC }\end{array}$ & Remarks \\
\hline OC & 57 & 57 & 22.7 & 0.000 & 0.000 & 0.00 & 0.16 & $0.37^{* *}$ & $0.38^{* *}$ & \\
\hline $\mathrm{EC}$ & 57 & 57 & 67.8 & 0.000 & 0.000 & $0.50^{* *}$ & $0.89^{* *}$ & $0.89^{* *}$ & - & $R(\mathrm{Cu} / \mathrm{EC})=0.83^{* *}$ \\
\hline $\mathrm{NO}_{x}$ & 55 & 55 & 73.9 & 0.000 & 0.000 & $0.49^{* *}$ & $0.71^{* *}$ & - & $0.89^{* *}$ & \\
\hline $\mathrm{PM}_{10}$ & 55 & 55 & 18.7 & 0.000 & 0.000 & $0.33^{*}$ & $0.33^{*}$ & $0.55^{* *}$ & $0.65^{* *}$ & \\
\hline $\mathrm{PM}_{2.5}$ & 48 & 48 & 21.3 & 0.000 & 0.000 & $0.38^{* *}$ & $0.31^{*}$ & $0.62^{* *}$ & $0.74 * *$ & \\
\hline PM $_{\text {coarse }}$ & 48 & 48 & 8.2 & 0.041 & 0.115 & 0.27 & 0.29 & 0.26 & 0.24 & \\
\hline $\mathrm{NO}_{3}^{-}$ & 48 & 48 & 28.4 & 0.000 & 0.000 & 0.18 & 0.27 & 0.23 & 0.21 & \\
\hline $\mathrm{Ca}^{2+}$ & 57 & 26 & 34.2 & 0.011 & 0.005 & $0.42^{* *}$ & $0.63^{* *}$ & $0.56^{* *}$ & $0.44^{* *}$ & $R(\mathrm{Ca} / \mathrm{Cu})=0.64^{* *}$ \\
\hline $\mathrm{Na}^{+}$ & 57 & 26 & 33.2 & 0.001 & 0.003 & 0.14 & $0.30^{*}$ & 0.19 & 0.04 & \\
\hline $\mathrm{Mg}^{2+}$ & 48 & 48 & 43.1 & 0.000 & 0.000 & 0.24 & $0.29 *$ & 0.17 & $0.33^{*}$ & $\begin{array}{l}R\left(\mathrm{Mg}^{2+} / \mathrm{NO}_{3}^{-}\right)=0.63^{* *} \\
R\left(\mathrm{Mg}^{2+} / \mathrm{Ti}\right)=0.57^{* *}\end{array}$ \\
\hline $\mathrm{Ba}$ & 57 & 26 & 37.2 & 0.035 & 0.013 & $0.49^{* *}$ & 0.26 & 0.25 & $0.35^{* *}$ & $\begin{array}{l}R(\mathrm{Ba} / \mathrm{Cu})=0.57^{* *} \\
R(\mathrm{Ba} / \mathrm{Sn})=0.74^{* *} \\
R(\mathrm{Ba} / \mathrm{Fe})=0.71^{* *}\end{array}$ \\
\hline Co & 57 & 26 & 35.6 & 0.003 & 0.000 & 0.15 & 0.07 & 0.00 & 0.04 & $\begin{array}{l}R\left(\mathrm{Co} / \mathrm{SO}_{4}^{2-}\right)=0.46^{* *} \\
R\left(\mathrm{Co} / \mathrm{oxalates}^{2}=0.51^{* *}\right. \\
R\left(\mathrm{Co} / \mathrm{NH}_{4}^{+}\right)=0.41^{* *}\end{array}$ \\
\hline $\mathrm{Cr}$ & 57 & 26 & $86.2^{\mathrm{a}}$ & 0.000 & 0.000 & 0.03 & 0.25 & $0.31^{*}$ & $0.40^{* *}$ & $\begin{array}{l}R\left(\mathrm{Cr} / \mathrm{Mn}=0.52^{* *}\right) \\
R(\mathrm{Cr} / \mathrm{Fe})=0.45^{* *}\end{array}$ \\
\hline $\mathrm{Cu}$ & 57 & 26 & 68.9 & 0.000 & 0.000 & $0.67^{* *}$ & $0.64^{* *}$ & $0.79^{* *}$ & $0.83^{* *}$ & $\begin{array}{l}R(\mathrm{Cu} / \mathrm{Sn})=0.95^{* *} \\
R(\mathrm{Cu} / \mathrm{Sb})=0.79^{* *} \\
R(\mathrm{Cu} / \mathrm{Ti})=0.68^{* *} \\
R(\mathrm{Cu}-\mathrm{An}, \mathrm{Fla}, \mathrm{Py}, \mathrm{H} 3 \\
\mathrm{H} 4)>0.5^{* *}\end{array}$ \\
\hline $\mathrm{Fe}$ & 57 & 26 & 84.1 & 0.000 & 0.000 & $0.68^{* *}$ & $0.60^{* *}$ & $0.67^{* *}$ & $0.74^{* *}$ & $\begin{array}{l}R(\mathrm{Cu} / \mathrm{Fe})=0.86^{* *} \\
R(\mathrm{Fe} / \mathrm{Sn})=0.92^{* *}\end{array}$ \\
\hline $\mathrm{Mn}$ & 57 & 26 & 59.6 & 0.000 & 0.000 & $0.48^{* *}$ & $0.66^{* *}$ & $0.78^{* *}$ & $0.77^{* *}$ & \\
\hline $\mathrm{Sb}$ & 57 & 26 & 63.3 & 0.000 & 0.000 & $0.44^{* *}$ & $0.61^{* *}$ & $0.71^{* *}$ & $0.62^{* *}$ & $R(\mathrm{Sb} / \mathrm{Sn})=0.81^{* *}$ \\
\hline Sn & 57 & 26 & 54.1 & 0.000 & 0.000 & $0.71^{* *}$ & $0.70^{* *}$ & $0.77^{* *}$ & $0.79^{* *}$ & \\
\hline $\mathrm{Sr}$ & 57 & 26 & $89.2^{\mathrm{a}}$ & 0.000 & 0.000 & $0.34 * *$ & $0.41^{* *}$ & $0.31^{*}$ & $0.28^{*}$ & \\
\hline $\mathrm{Ti}$ & 57 & 26 & 60.8 & 0.003 & 0.001 & $0.58^{* *}$ & $0.59^{* *}$ & $0.44^{* *}$ & $0.45^{* *}$ & $R(\mathrm{Ti} / \mathrm{Al})=0.42^{* *}$ \\
\hline
\end{tabular}

${ }^{\text {a }}$ Concentrations at Les Frênes are most of the time below the detection limit. ${ }^{*}$ means statistically significant at the $95 \%$ level. ** means statistically significant at the $99 \%$ level. Species significantly correlated with traffic indicators and for which local traffic contributions are above $50 \%$ are highlighted.

et al. (2011a) and Harrison et al. (2012) measured strong increments for $\mathrm{Fe}, \mathrm{Cu}, \mathrm{Sb}$ and $\mathrm{Sn}$ concentrations at traffic sites with strong correlations between them. Here, $\mathrm{Cu}, \mathrm{Fe}$ and $\mathrm{Sn}$ are the metals that are the most closely related (Pearson $\left.r^{2} \geq 0.8\right)$, while relationships with $\mathrm{Mn}$ and $\mathrm{Sb}$ are more scattered (Pearson $\left.r^{2}<0.5\right)$ and more closely related to the heavy-duty traffic (Table 1a).

$\mathrm{Cr}$ and $\mathrm{Ti}$ are also species significantly correlated to traffic indicators but to a lower extent than $\mathrm{Cu}, \mathrm{Fe}, \mathrm{Mn}, \mathrm{Sb}$ and
Sn. Cr (Boogaard et al., 2011; Amato et al., 2011a) and Ti (Amato et al., 2011a) also showed higher atmospheric concentrations at street locations than at urban background sites in previous studies. $\mathrm{Cr}$ and $\mathrm{Ti}$ show a behaviour different from that of other elements coming from brake wear. They present sharp peaks in the morning, poorer correlations with copper and significant correlations with $\mathrm{Al}$ (Fig. 4 and Table 1a). When the very high morning concentrations are removed (mornings of workdays), their temporal variations are 
Table 1. Continued.

\begin{tabular}{|c|c|c|c|c|c|c|c|c|c|c|}
\hline Pollutant & $N_{\mathrm{T}}$ & $N_{\mathrm{UB}}$ & $\begin{array}{r}\text { Median } \\
\text { increment }(\%)\end{array}$ & $\begin{array}{c}\text { Sign test } \\
p \text { value }\end{array}$ & $\begin{array}{r}\text { Wilcoxon } \\
\text { signed-rank } \\
\text { test } p \text { value }\end{array}$ & $\begin{array}{r}R \text { with } \\
\text { total traffic }\end{array}$ & $\begin{array}{r}R \text { with } \\
\text { HDV }\end{array}$ & $\begin{array}{r}R \text { with } \\
\mathrm{NO}_{x}\end{array}$ & $\begin{array}{r}R \text { with } \\
\text { EC }\end{array}$ & Remarks \\
\hline Phe (phenanthrene) & 56 & 40 & 43.8 & 0.000 & 0.000 & 0.17 & 0.17 & 0.25 & $0.32 *$ & \\
\hline An (anthracene) & 56 & 40 & 55.0 & 0.000 & 0.000 & $0.34^{*}$ & $0.39^{* *}$ & $0.48^{* *}$ & $0.51^{* *}$ & \\
\hline Fla (fluoranthene) & 56 & 40 & 70.3 & 0.000 & 0.000 & $0.38^{* *}$ & $0.43^{* *}$ & $0.51^{* *}$ & $0.54^{* *}$ & \\
\hline Pyr (pyrene) & 56 & 40 & 81.3 & 0.000 & 0.000 & $0.40^{* *}$ & $0.46^{* *}$ & $0.50^{* *}$ & $0.51^{* *}$ & \\
\hline BaA (benzo(a)anthracene) & 56 & 40 & 55.3 & 0.000 & 0.000 & 0.16 & 0.23 & $0.29 *$ & $0.39^{* *}$ & $\begin{array}{l}\text { Correlation with } \\
\text { levoglucosan: } \\
0.75^{* *}\end{array}$ \\
\hline C17 (heptadecane) & 56 & 40 & 78.7 & 0.005 & 0.001 & -0.03 & 0.09 & 0.21 & 0.24 & \\
\hline C18 (octadecane) & 56 & 40 & 39.6 & 0.010 & 0.004 & 0.14 & 0.22 & $0.36^{* *}$ & $0.43^{* *}$ & \\
\hline C19 (nonadecane) & 56 & 40 & 83.1 & 0.000 & 0.000 & 0.23 & $0.29^{*}$ & $0.39^{* *}$ & $0.39^{* *}$ & \\
\hline C20 (icosane) & 56 & 40 & 70.0 & 0.000 & 0.000 & 0.24 & $0.39^{* *}$ & $0.50^{* *}$ & $0.42^{* *}$ & \\
\hline C21 (henicosane) & 56 & 40 & 89.0 & 0.000 & 0.000 & 0.21 & $0.33^{*}$ & $0.46^{* *}$ & $0.41^{* *}$ & \\
\hline C22 (docosane) & 56 & 40 & 79.3 & 0.000 & 0.000 & $0.27^{*}$ & $0.41^{* *}$ & $0.52^{* *}$ & $0.43^{* *}$ & \\
\hline C23 (tricosane) & 56 & 40 & 66.6 & 0.000 & 0.000 & $0.31^{*}$ & $0.40^{* *}$ & $0.61^{* *}$ & $0.59^{* *}$ & \\
\hline C24 (tetracosane) & 56 & 40 & 68.3 & 0.000 & 0.000 & 0.26 & $0.35^{*}$ & $0.50^{* *}$ & $0.63^{* *}$ & \\
\hline C25 (pentacosane) & 56 & 40 & 48.2 & 0.000 & 0.000 & 0.24 & $0.29^{*}$ & $0.55^{* *}$ & $0.61^{* *}$ & \\
\hline C26 (hexacosane) & 56 & 40 & 70.3 & 0.000 & 0.000 & 0.22 & $0.36^{* *}$ & $0.62^{* *}$ & $0.63^{* *}$ & \\
\hline C27 (heptacosane) & 56 & 40 & 36.4 & 0.000 & 0.000 & 0.17 & 0.18 & $0.36^{* *}$ & $0.44^{* *}$ & \\
\hline C28 (octacosane) & 56 & 40 & 57.4 & 0.026 & 0.000 & -0.15 & -0.01 & 0.19 & 0.22 & $\begin{array}{l}\text { Correlation with } \\
\text { levoglucosan: } \\
0.55^{* *}\end{array}$ \\
\hline C29 (nonacosane) & 56 & 40 & 32.0 & 0.006 & 0.000 & 0.15 & 0.16 & 0.24 & 0.26 & $\begin{array}{l}\text { Correlation with } \\
\text { levoglucosan: } \\
0.39^{* *}\end{array}$ \\
\hline C30 (triacontane) & 56 & 40 & 54.7 & 0.002 & 0.000 & 0.03 & 0.16 & $0.33^{*}$ & $0.38^{* *}$ & $\begin{array}{l}\text { Correlation with } \\
\text { levoglucosan: } \\
0.51^{* *}\end{array}$ \\
\hline C31 (hentriacontane) & 56 & 40 & 20.4 & 0.007 & 0.003 & 0.14 & 0.21 & $0.35^{*}$ & $0.41^{* *}$ & $\begin{array}{l}\text { Correlation with } \\
\text { levoglucosan: } \\
0.48^{* *}\end{array}$ \\
\hline C32 (dotriacontane) & 56 & 40 & 63.4 & 0.004 & 0.002 & -0.18 & -0.06 & 0.13 & 0.21 & $\begin{array}{l}\text { Correlation with } \\
\text { levoglucosan: } \\
0.47^{* *}\end{array}$ \\
\hline C33 (tritriacontane) & 56 & 40 & 34.4 & 0.030 & 0.008 & -0.03 & 0.07 & 0.23 & $0.32^{*}$ & $\begin{array}{l}\text { Correlation with } \\
\text { levoglucosan: } \\
0.47^{* *}\end{array}$ \\
\hline H3 (17 $221 \beta$ norhopane) & 56 & 40 & $97.4^{\mathrm{a}}$ & 0.000 & 0.000 & $0.29^{*}$ & $0.46^{* *}$ & $0.67^{* *}$ & $0.67^{* *}$ & \\
\hline H4 (17 $\alpha 21 \beta$ hopane) & 56 & 40 & $97.8^{\mathrm{a}}$ & 0.000 & 0.000 & 0.22 & $0.37^{* *}$ & $0.59^{* *}$ & $0.61^{* *}$ & \\
\hline
\end{tabular}

correlated with traffic indicators and for which local traffic contributions are above $50 \%$ are highlighted.

much closer to the ones of metals from brake-wear emissions. This suggests that another source influenced $\mathrm{Cr}$ and Ti concentrations near the traffic site in the morning, possibly nearby metalworking activities. Similarly, while morning peaks are less obvious in the temporal variations, the exclusion of morning data for $\mathrm{Fe}$ and $\mathrm{Mn}$ improves their correlations with $\mathrm{Cu}$ (Fig. 4).

Many of these species are metals that are known to arise from brake-wear emissions (Thorpe and Harrison, 2008; Pant and Harrison, 2013; Grigoratos and Martini, 2015). Indeed, Fe could come from the lining (steel or iron powder) in semimetallic brakes, from fibres such as steel, or cast iron rotor wear for slightly metallic brakes. $\mathrm{Cu}$ is a high-temperature lubricant present in linings and it is also included in fibres as brass to increase braking performance. $\mathrm{Sb}$ is an element of brake lining both in filler as antimony sulfate and in lubricant as antimony trisulfide. Chromium oxides are elements of the filler of brake linings used for their thermal properties, and potassium titanate fibers are present as a strengthener in organic linings (Sanders et al., 2003; Grigoratos and Martini, 2014, and references therein). Cr could also come from lubricant oil combustion (Pulles et al., 2012).

Only three light-molecular-weight PAHs (An, Fla, Pyr) are strongly associated with traffic indicators even though only the particulate phase is determined (Table 1b). It is well-established that light-molecular-weight PAHs are emitted by diesel vehicles, while higher-molecular-weight PAHs are rather associated with petrol vehicle emissions (Zielinska et al., 2004; Phuleria et al., 2006, 2007; Pant and Harrison, 2013). Not surprisingly, in this site dominated by diesel vehicles, high-molecular-weight PAHs (from five rings) are more significantly correlated with levoglucosan, suggesting 
Table 2. (a) Median emission factors for OC, EC and major ions significantly related to traffic and interquartile range (IQR: 25 th and 75th percentiles) in $\mathrm{mg} \mathrm{veh}^{-1} \mathrm{~km}^{-1}$. (b) Median emission factors for elements significantly related to traffic and interquartile range (IQR: 25th and 75th percentiles) in $\mu \mathrm{g} \mathrm{veh}{ }^{-1} \mathrm{~km}^{-1}$. (c) Median emission factors for PAHs significantly related to traffic and $17 \alpha 21 \beta$ norhopane (H3), $17 \alpha 21 \beta$ hopane (H4) and their interquartile range (IQR: 25 th and 75 th percentiles) in $\mu \mathrm{g} \mathrm{veh}^{-1} \mathrm{~km}^{-1}$. (d) Median emission factors for $n$-alkanes significantly related to traffic and interquartile range (IQR: 25th and 75th percentiles) in $\mu \mathrm{g} \mathrm{veh}^{-1} \mathrm{~km}^{-1}$.

\begin{tabular}{|c|c|c|c|c|c|c|c|c|c|}
\hline (a) & & & & & & & & & \\
\hline EFs & $\mathrm{OC}$ & $\mathrm{EC}$ & $\mathrm{NO}_{3}^{-}$ & $\mathrm{Na}^{+}$ & $\mathrm{Mg}^{2+}$ & $\mathrm{Ca}^{2+}$ & & & \\
\hline Median & 16.8 & 39.0 & 1.82 & 0.176 & 0.061 & 1.62 & & & \\
\hline IQR & $8.4-27.8$ & $35.5-45.5$ & $0.45-2.6$ & $0.104-0.394$ & $0.044-0.106$ & $0.80-2.27$ & & & \\
\hline \multicolumn{10}{|l|}{ (b) } \\
\hline EFs & $\mathrm{Ba}$ & $\mathrm{Cr}$ & $\mathrm{Cu}$ & $\mathrm{Fe}$ & $\mathrm{Mn}$ & $\mathrm{Sb}$ & $\mathrm{Sn}$ & $\mathrm{Sr}$ & $\mathrm{Ti}$ \\
\hline Median & 66 & 43 & 300 & 6711 & 62 & 27 & 55 & 11 & 28 \\
\hline IQR & $20-136$ & $38-75$ & $228-450$ & 4527-9302 & $51-72$ & $19-39$ & $40-81$ & $8-16$ & $22-40$ \\
\hline \multicolumn{10}{|l|}{ (c) } \\
\hline EFs & Phe & An & $\mathrm{Fla}$ & Pyr & $\mathrm{H} 3$ & $\mathrm{H} 4$ & & & \\
\hline Median & 0.716 & 0.054 & 1.69 & 2.54 & 3.46 & 4.34 & & & \\
\hline IQR & $0.346-1.15$ & $0.033-0.085$ & $1.14-2.37$ & $1.78-3.28$ & $1.99-6.90$ & $2.67-6.89$ & & & \\
\hline \multicolumn{10}{|l|}{ (d) } \\
\hline EFs & C19 & $\mathrm{C} 20$ & $\mathrm{C} 21$ & $\mathrm{C} 22$ & $\mathrm{C} 23$ & $\mathrm{C} 24$ & $\mathrm{C} 25$ & $\mathrm{C} 26$ & \\
\hline Median & 3.6 & 9.5 & 30.3 & 42.5 & 48.0 & 39.9 & 19.8 & 12.7 & \\
\hline IQR & $2.0-8.3$ & $5.2-18.9$ & $19.9-62.4$ & $29.8-81.4$ & $30.6-70.3$ & $26.1-52.5$ & $12.5-34.2$ & $9.3-21.9$ & \\
\hline
\end{tabular}

a closer relation to biomass burning emissions than to onroad petrol vehicles. Proportional concentrations of An, Pyr and Fla suggest that they mainly come from the same source, likely diesel exhaust emissions (Figs. 3 and 4). Specifically, Pyr and Fla show high increments in concentration (as an indication of the low contribution of the urban background compared to strong traffic contribution, and/or rapid photochemical degradation) and a strong linear relationship without any significant intercept (as an indication of common origin). Concentrations of An have more variability and larger contribution from the urban background.

The $n$-alkanes C19 to C26 and two hopanes (17 $\alpha 21 \beta$ norhopane and $17 \alpha 21 \beta$ hopane) are species that are not significantly, or only weakly, correlated to total traffic. However, they are significantly correlated with $\mathrm{NO}_{x}$ and $\mathrm{EC}$ and some of them with heavy-duty traffic. The $n$-alkanes between $\mathrm{C} 18$ and $\mathrm{C} 25$ are the predominant ones in vehicle exhaust and correspond to the high boiling point components in diesel fuels (Alves et al., 2016). Hopanes are known to arise from unburnt lubricating oil emissions (Rogge et al., 1993a; Zielinska et al., 2004), and $17 \alpha 21 \beta$-norhopane is considered as a tracer for lubricating oil (Kleeman et al., 2008). While $n$-alkanes have been measured in the exhaust of test diesel vehicles in our study (Table 4), hopanes and steranes were below the quantification limit for all selected vehicles. It was assumed that the tested vehicles (passenger cars, none of which was a super-emitting vehicle) did not emit enough unburnt oil for the proper quantification of hopanes. At the sampling site, the temporal variations of the concentrations of these species show higher values on the second week of the field campaign than on the first one. This observation can be explained by much larger heavy-duty traffic during this period (almost twice the traffic of the first week).

\subsubsection{Other species}

This second group corresponds to species with local increments below $50 \%$ and no significant, or only weak, correlations with traffic indicators. It is highly heterogeneous since it includes $\mathrm{OC}, \mathrm{NO}_{3}^{-}, \mathrm{Na}^{+}, \mathrm{Ca}^{2+}, \mathrm{Mg}^{2+}, \mathrm{Ba}, \mathrm{Co}$, phenanthrene (Phe), benzo(a)anthracene (BaA) and some $n$-alkanes (C18, and from $\mathrm{C} 27$ to $\mathrm{C} 33$ ). Most of the species from this group are obviously emitted by the traffic, but they seem to be less specific than species from the first group since other sources can largely contribute to their emission levels.

Not surprisingly $\mathrm{NO}_{3}^{-}$is not significantly related to primary traffic indicators. However its concentrations are significantly higher at the traffic site ( $p<0.001$, and median increment of $28 \%$ ). Additionally, the temporal pattern of $\mathrm{NO}_{3}^{-}$is different from that of indicators of regional origin (for example $\mathrm{SO}_{4}^{2-}$, Supplement Sect. VII). Amato et al. (2011a) found similar contributions of traffic to $\mathrm{NO}_{3}^{-}$concentrations at two 
(a)

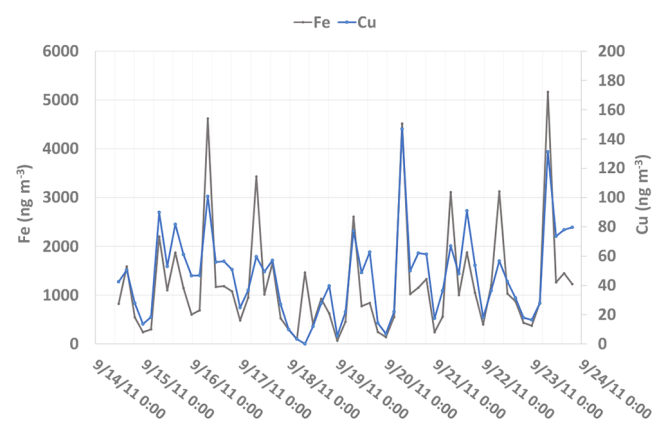

(c)

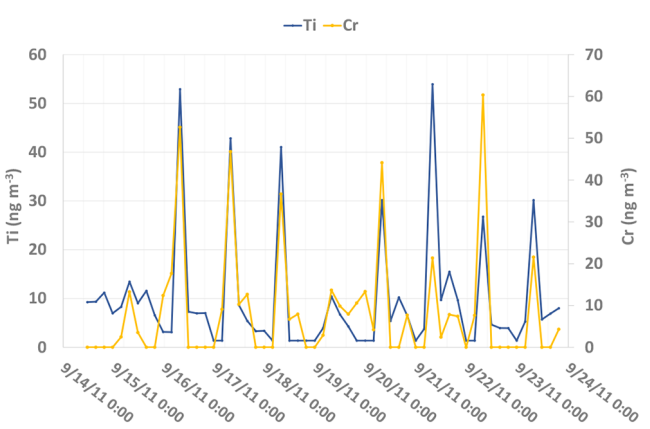

(e)

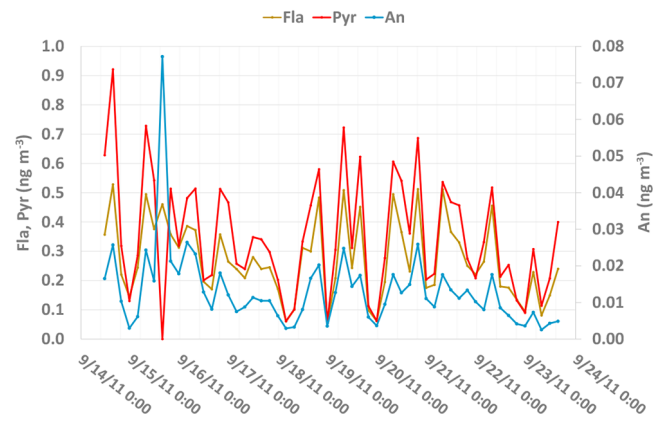

(b)

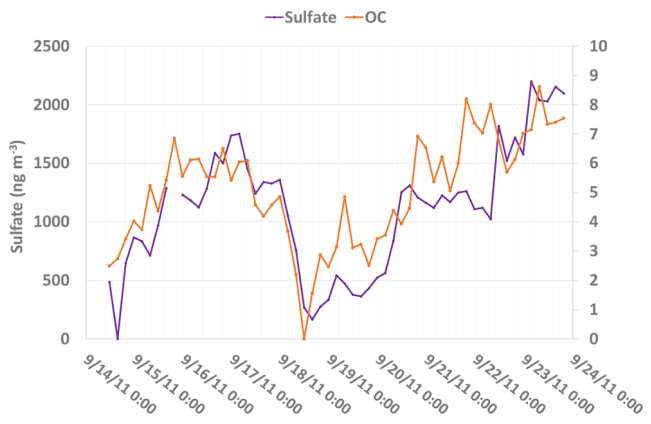

(d)

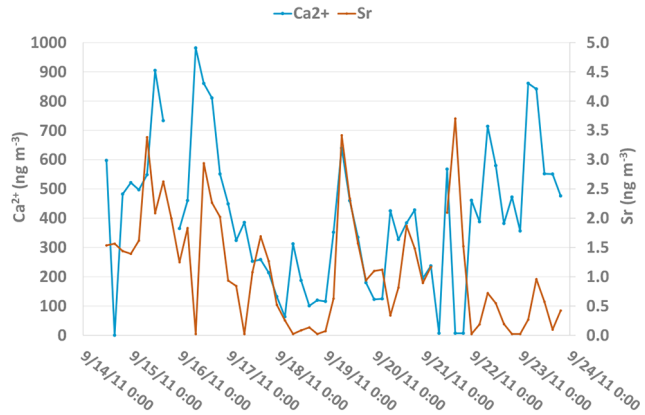

(f)

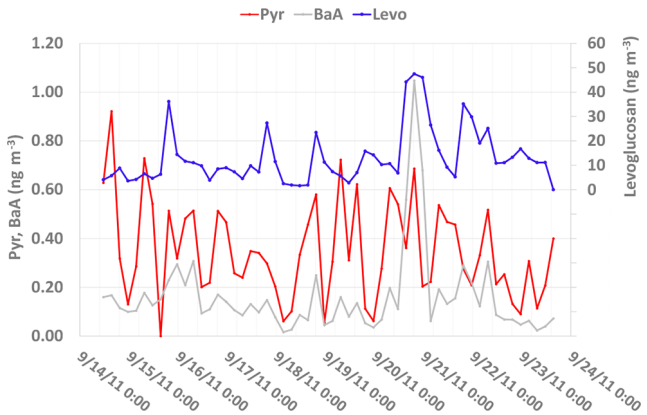

Figure 3. The $4 \mathrm{~h}$ concentrations measured at the traffic site: (a) iron and copper; (b) sulfate and organic carbon; (c) chromium and titanium; (d) calcium and strontium; (e) fluoranthene, pyrene and anthracene; and (f) pyrene, benzo(a)anthracene and levoglucosan.

traffic sites in Barcelona (34\% and 25\%, respectively). They assumed that $\mathrm{NH}_{4} \mathrm{NO}_{3}$ is quickly formed in the road plume enriched in $\mathrm{NH}_{3}$ emitted by vehicles. Indeed, the important introduction of vehicles equipped with DeNOx technology such as three-way catalysts or selective catalytic reduction systems has led to recent increasing vehicular $\mathrm{NH}_{3}$ emissions (Kean et al., 2009; Suarez-Bertoa and Astorga, 2016) responsible for significant changes in the chemistry of the atmosphere in roadside areas.

OC concentrations are significantly higher at the traffic site $(p<0.001$; increment of $23 \%)$ and are weakly but significantly correlated with traffic indicators. Amato et al. (2011a) found slightly higher increments of $34 \%$ and $41 \%$ for OC at their two traffic sites. Deconvolution of sources from simultaneous $\mathrm{PM}_{1}$ AMS measurements concluded that about
$20 \%$ of the total $\mathrm{PM}_{1}$ organic mass could be attributed to vehicular emissions (DeWitt et al., 2015). Additionally, the temporal pattern of OC concentrations clearly shows a dominant regional contribution (Fig. 3 and Supplement Sect. VII). All these results agree that in, summertime, the majority of $\mathrm{OC}$ is of regional origin, despite a clear influence of traffic.

$\mathrm{Na}^{+}, \mathrm{Ca}^{2+}, \mathrm{Mg}^{2+}$ and $\mathrm{Sr}$ concentrations are also significantly higher at the traffic site $(p<0.05$, increments from $33 \%$ to $43 \%$, except for $\mathrm{Sr}$ for which urban background concentrations are most of the time below the detection limit). When three high concentrations for $\mathrm{Mg}^{2+}$ concentrations and one for $\mathrm{Sr}$ concentration are excluded (all probably not related to traffic), both present temporal variations close to that of calcium (Fig. 3). All are at least significantly correlated to the heavy-duty traffic $(p<0.05)$. Since $\mathrm{Ca}^{2+}, \mathrm{Mg}^{2+}$ and $\mathrm{Sr}$ 
(a)

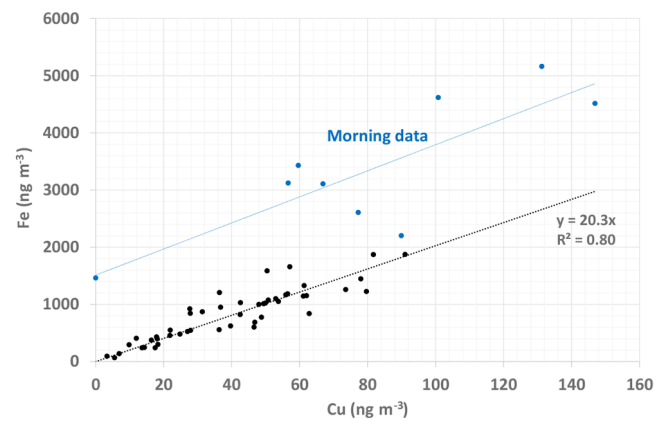

(c)

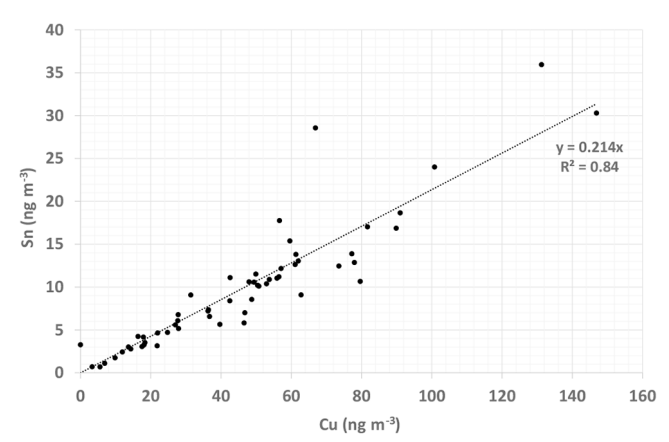

(e)

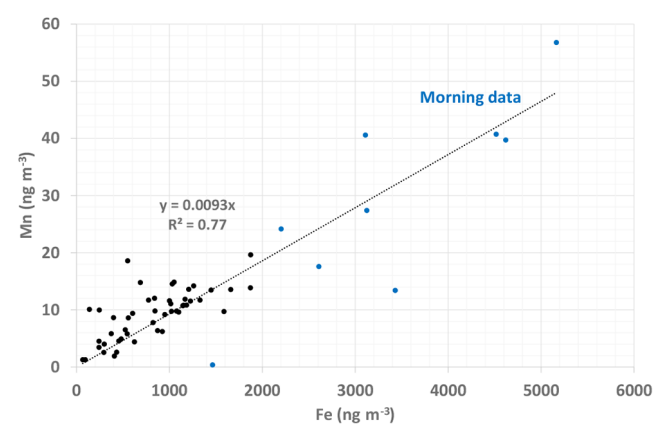

(g)

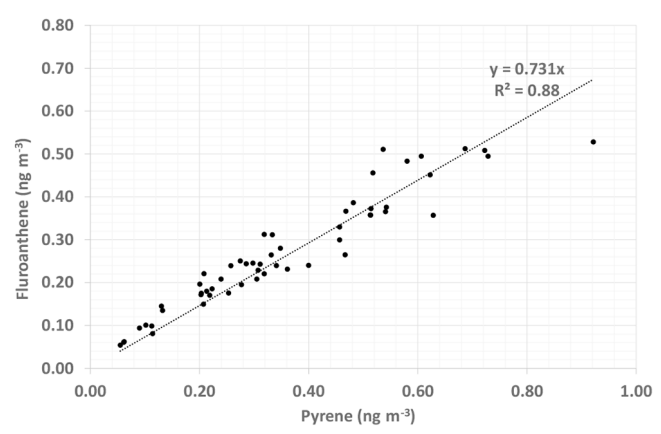

(b)

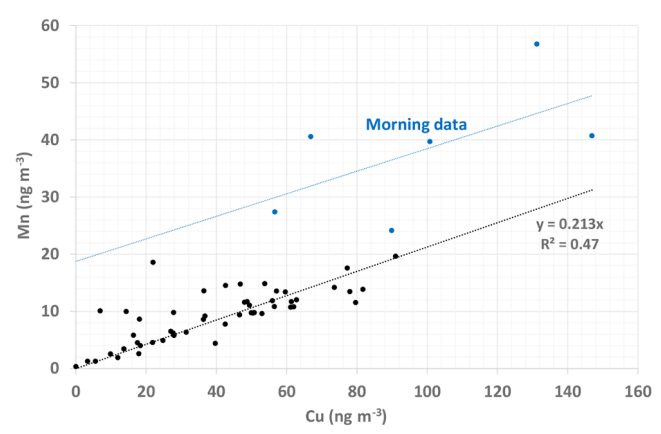

(d)

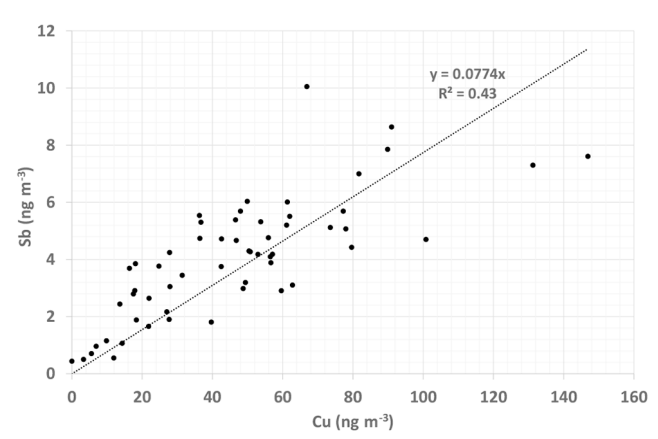

(f)

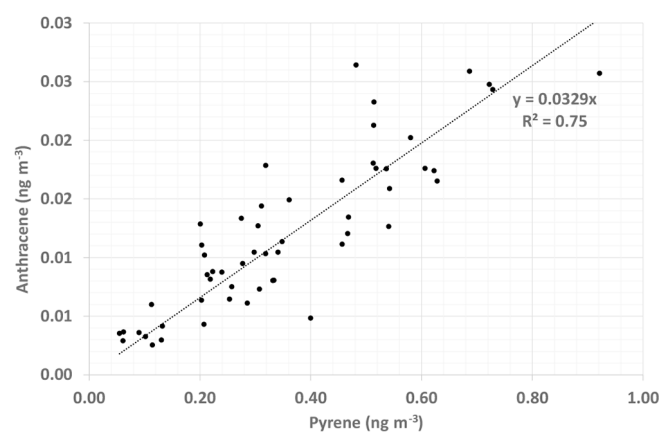

(h)

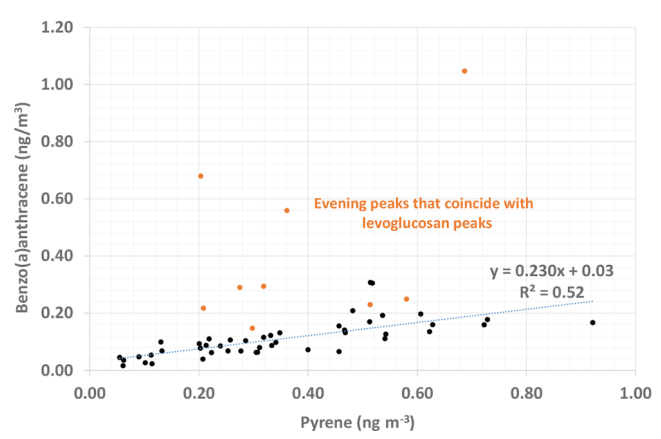

Figure 4. Scatterplots and linear relationships for a few species: (a) iron vs. copper, (b) manganese vs. copper, (c) tin vs. copper, (d) antimony vs. copper, (e) manganese vs. iron, (f) anthracene vs. pyrene, (g) fluoranthene vs. pyrene and (h) benzo(a)anthracene vs. pyrene. 
Table 3. Results of the multiple linear regressions with the heavy-duty traffic (HDV) and the light-duty traffic (LDV): square correlation coefficients, unstandardized coefficients with standard deviations for HDV and LDV, $p$ values and $95 \%$ confidence intervals (CI).

\begin{tabular}{|c|c|c|c|c|c|c|c|c|c|c|c|c|}
\hline & \multirow{2}{*}{ Unit } & \multirow{2}{*}{$r^{2}$} & \multicolumn{5}{|c|}{ HDV } & \multicolumn{5}{|c|}{ LDV } \\
\hline & & & Coeff. & SD & $p \mid$ & \multicolumn{2}{|c|}{$95 \% \mathrm{CI}$} & Coeff. & SD & $p$ & \multicolumn{2}{|c|}{$95 \% \mathrm{CI}$} \\
\hline $\mathrm{EC}$ & $\mathrm{mg} \mathrm{veh}^{-1} \mathrm{~km}^{-1}$ & 0.92 & 148.4 & 22.7 & 0.000 & 102.9 & 193.9 & 30.2 & 1.9 & 0.000 & 26.4 & 34.0 \\
\hline $\mathrm{Cu}$ & $\mu \mathrm{g} \mathrm{veh}-1 \mathrm{~km}^{-1}$ & 0.73 & 3371 & 990 & 0.003 & 1312 & 5430 & 258 & 104 & 0.021 & 42 & 474 \\
\hline $\mathrm{Fe}$ & $\mathrm{mg} \mathrm{veh}^{-1} \mathrm{~km}^{-1}$ & 0.81 & 48.0 & 19.1 & 0.023 & 7.5 & 88.5 & 6.3 & 1.7 & 0.002 & 2.7 & 9.8 \\
\hline $\mathrm{Sb}$ & $\mu \mathrm{g} \mathrm{veh}-1 \mathrm{~km}^{-1}$ & 0.77 & 246 & 72 & 0.003 & 96 & 395 & 20.1 & 6.9 & 0.006 & 5.6 & 34.5 \\
\hline Sn & $\mu \mathrm{g} \mathrm{veh}^{-1} \mathrm{~km}^{-1}$ & 0.82 & 512 & 149 & 0.003 & 198 & 825 & 54 & 15 & 0.002 & 23 & 85 \\
\hline Pyr & $\mu \mathrm{g} \mathrm{veh}^{-1} \mathrm{~km}^{-1}$ & 0.60 & 28.4 & 6.3 & 0.000 & 15.6 & 41.1 & 1.459 & 0.658 & 0.034 & 0.121 & 2.798 \\
\hline An & $\mu \mathrm{g} \mathrm{veh}^{-1} \mathrm{~km}^{-1}$ & 0.55 & 0.435 & 0.128 & 0.002 & 0.174 & 0.697 & 0.0352 & 0.0131 & 0.011 & 0.0086 & 0.0618 \\
\hline Fla & $\mu \mathrm{g} \mathrm{veh}{ }^{-1} \mathrm{~km}^{-1}$ & 0.58 & 7.38 & 3.38 & 0.037 & 0.49 & 14.27 & 1.254 & 0.305 & 0.000 & 0.632 & 1.875 \\
\hline $\mathrm{C} 23$ & $\mu \mathrm{g} \mathrm{veh}{ }^{-1} \mathrm{~km}^{-1}$ & 0.66 & 277.8 & 70.6 & 0.000 & 133.8 & 421.7 & 23.9 & 6.3 & 0.001 & 11.1 & 36.8 \\
\hline $\mathrm{C} 24$ & $\mu \mathrm{g} \mathrm{veh}{ }^{-1} \mathrm{~km}^{-1}$ & 0.62 & 163.9 & 54.0 & 0.005 & 53.7 & 274.1 & 19.2 & 4.8 & 0.000 & 9.3 & 29.0 \\
\hline
\end{tabular}

are strongly affected by rain events (assumed to influence the silt loading of the road), their incremental concentrations are believed to be from resuspended dust, as concluded in other studies (e.g. Lough et al., 2007; Amato al., 2011a).

$\mathrm{Ba}$ and Co concentrations are significantly higher at the traffic site $(p<0.05$, increments of $37 \%$ and $36 \%$, respectively). Ba concentrations present a temporal behaviour close to the ones of $\mathrm{Cu}, \mathrm{Fe}, \mathrm{Sn}$ and $\mathrm{Mn}$ and, accordingly, are known as an element of the filler of brake linings. Higher $\mathrm{Ba}$ atmospheric concentrations at street locations than at urban background sites have also been observed in previous studies (Harrison et al., 2012). On the contrary, Co concentrations do not show any correlation with traffic indicators and are correlated with tracers of regional origin (Table 1a). Co is sometimes measured in brake pads (e.g. Hulskotte et al., 2014), and Amato et al. (2011a) found similar increments for Co at their traffic sites (respectively $33 \%$ and $47 \%$ ). All of these suggest that a possible contribution of brake wear to Co concentrations cannot be excluded, despite the lack of correlation with traffic indicators.

The concentrations of Phe, BaA, C18 and C27-C33 alkanes are significantly higher at the traffic site and some of them are significantly correlated with $\mathrm{NO}_{x}$ and EC. Accordingly these species were detected in the exhaust emissions of diesel vehicles sampled from our chassis dynamometer experiments. However most of them are also significantly correlated with levoglucosan measured at the traffic site, particularly $\mathrm{BaA}$. Indeed the temporal pattern of $\mathrm{BaA}$ shows similarities with both the one of Pyr (strongly related to traffic, see below) and levoglucosan (tracer of biomass burning peaking in the evening) (Fig. 3). It is therefore believed that most of them are largely emitted by biomass burning and are not specific to road traffic emissions.

\subsection{Quantification of traffic-fleet emissions for species associated with traffic}

Average emission factors (EFs) are presented in Table 2a, b, c and d. Most EFs show large standard deviations. This variability reflects the presence of vehicles with various emission levels (diesel/petrol; different standards and engine load; cold start/hot vehicles; presence of a few high-emitting vehicles). It could also be related to the variability in the vehicle fleet (on average 5\% heavy vehicles but ranging from $0.3 \%$ to $12 \%$ ) and to the various traffic conditions (from fluid with speeds up to $90 \mathrm{~km} \mathrm{~h}^{-1}$ to congested with stop-and-go traffic).

Table 3 presents average EFs for heavy-duty and lightduty traffic, their standard deviations and confidence intervals at $95 \%$.

\subsubsection{EC/OC emissions}

The traffic-fleet EF for EC determined in this study (39 $\mathrm{mg} \mathrm{veh}^{-1} \mathrm{~km}^{-1}$ ) is slightly higher than the ones determined in tunnel studies in Austria, China, California and near a heavily trafficked highway in Switzerland (about $21 \mathrm{mg} \mathrm{veh}^{-1} \mathrm{~km}^{-1}$ for Handler et al., 2008; Hueglin et al., 2006; and Cui et al., 2016; and $31 \mathrm{mg} \mathrm{veh}^{-1} \mathrm{~km}^{-1}$ for Gillies et al., 2001), while it is similar to the one of a tunnel study in Portugal (39 mg veh ${ }^{-1} \mathrm{~km}^{-1}$ ) (Alves et al., 2015). Conversely, the traffic-fleet EFs for OC in Austria and China (about $19 \mathrm{mg} \mathrm{veh}^{-1} \mathrm{~km}^{-1}$ ) are similar to ours, while the ones for urban tunnels in Portugal (Alves et al., 2015) and the US (Gillies et al., 2001) are higher (39 and $25 \mathrm{mg} \mathrm{veh}^{-1} \mathrm{~km}^{-1}$, respectively). Different traffic-fleet and traffic conditions may explain these small divergences. Part of the differences may also be due to the different measurement techniques used for the distinction between EC and OC.

The average light-duty-traffic-fleet EF for EC is in excellent agreement with the EFs of Euro 3 and Euro 4 diesel ve- 
Table 4. Average emissions factors (median and IQR: interquartile range) determined by chassis dynamometer measurements for different types of passenger cars: Euro 3 diesel (E3D), Euro 4 diesel (E4D), Euro 2 petrol (E2P), Euro 4 petrol (E4P) and Euro 4 diesel equipped with a particle filter $(\mathrm{E} 4 \mathrm{D}+\mathrm{PF})$ using urban, urban cold and road real driving cycles. Und: undetermined.

\begin{tabular}{|c|c|c|c|c|c|c|c|c|c|c|c|}
\hline & \multirow{2}{*}{ Unit } & \multicolumn{2}{|c|}{ E3D } & \multicolumn{2}{|c|}{ E4D } & \multicolumn{2}{|c|}{ E2P } & \multicolumn{2}{|c|}{ E4P } & \multicolumn{2}{|c|}{$\mathrm{E} 4 \mathrm{D}+\mathrm{PF}$} \\
\hline & & Median & IQR & Median & IQR & Median & IQR & Median & IQR & Median & IQR \\
\hline $\mathrm{EC}$ & $\mathrm{mg} \mathrm{km}^{-1}$ & 31.6 & $29.7-41.2$ & 27.1 & $15.8-37.4$ & $<\mathrm{QL}$ & $<\mathrm{QL}$ & 0.06 & $0-0.06$ & 0.37 & $0.12-0.44$ \\
\hline $\mathrm{OC}$ & $\mathrm{mg} \mathrm{km}^{-1}$ & 10.7 & $7.3-14.4$ & 5.6 & $3.3-6.0$ & 0.3 & $0.2-0.4$ & $<\mathrm{QL}$ & $<\mathrm{QL}$ & 0.14 & $0.07-0.18$ \\
\hline $\mathrm{OC} / \mathrm{EC}$ & - & 0.29 & $0.24-0.33$ & 0.16 & $0.12-0.19$ & und. & und. & und. & und. & 0.61 & $0.40-1.94$ \\
\hline $\mathrm{Ba}$ & $\mu \mathrm{g} \mathrm{km}^{-1}$ & 25.0 & $17.7-48.9$ & 27.3 & $13.6-30.3$ & 3. 6 & $2.8-5.0$ & - & - & 0 & $0-0.2$ \\
\hline Co & $\mu \mathrm{g} \mathrm{km}^{-1}$ & $<\mathrm{DL}$ & $<\mathrm{DL}$ & $<\mathrm{DL}$ & $<\mathrm{DL}$ & $<\mathrm{DL}$ & $<\mathrm{DL}$ & - & - & $<\mathrm{DL}$ & $<\mathrm{DL}$ \\
\hline $\mathrm{Cr}$ & $\mu \mathrm{g} \mathrm{km}^{-1}$ & 0.92 & $0.46-5.7$ & 2.7 & $1.3-2.9$ & 0.91 & $0.75-1.1$ & - & - & 0.16 & $0.08-0.27$ \\
\hline $\mathrm{Cu}$ & $\mu \mathrm{g} \mathrm{km}^{-1}$ & 9.2 & $5.2-12.9$ & 1.1 & $0.56-2.4$ & 0.40 & $0.33-0.79$ & - & - & 0.14 & $0.10-0.29$ \\
\hline $\mathrm{Fe}$ & $\mu \mathrm{g} \mathrm{km}^{-1}$ & 84 & $48-213$ & 51 & $25-98$ & 22 & $20-27$ & - & - & 0.93 & $0.47-2.5$ \\
\hline $\mathrm{Mn}$ & $\mu \mathrm{g} \mathrm{km}^{-1}$ & 0.56 & $0.49-4.3$ & 4.2 & $2.4-4.3$ & 0.42 & $0.13-0.81$ & - & - & 0.07 & $0.03-0.09$ \\
\hline $\mathrm{Sb}$ & $\mu \mathrm{g} \mathrm{km}^{-1}$ & $<\mathrm{DL}$ & $<\mathrm{DL}$ & $<\mathrm{DL}$ & $<\mathrm{DL}$ & $<\mathrm{DL}$ & $<\mathrm{DL}$ & - & - & $<\mathrm{DL}$ & $<\mathrm{DL}$ \\
\hline $\mathrm{Sn}$ & $\mu \mathrm{g} \mathrm{km}^{-1}$ & 0.92 & $0.46-5.4$ & 2.25 & $1.1-2.6$ & 0.06 & $0-0.14$ & - & - & 0.06 & $0.03-0.08$ \\
\hline $\mathrm{Sr}$ & $\mu \mathrm{g} \mathrm{km}^{-1}$ & 0.67 & $0.48-1.0$ & 0.68 & $0.60-1.5$ & 0.15 & $0.10-0.31$ & - & - & 0.02 & $0.01-0.04$ \\
\hline $\mathrm{Ti}$ & $\mu \mathrm{g} \mathrm{km}^{-1}$ & 8.3 & $7.4-10.7$ & 15.6 & $12.0-28.1$ & 2.8 & $1.5-4.4$ & - & - & $<$ DL & $0-0.1$ \\
\hline $\mathrm{Ca}^{2+}$ & $\mu \mathrm{g} \mathrm{km}^{-1}$ & $<\mathrm{DL}$ & $0-109$ & 39 & $0-52$ & $<\mathrm{DL}$ & $<\mathrm{DL}$ & $<\mathrm{DL}$ & $<\mathrm{DL}$ & 1.2 & $1.0-2.8$ \\
\hline $\mathrm{Na}^{+}$ & $\mu \mathrm{g} \mathrm{km}^{-1}$ & $<\mathrm{DL}$ & $0-89$ & $<\mathrm{DL}$ & $0-60$ & 3.6 & $2.7-6.0$ & $<\mathrm{DL}$ & $<\mathrm{DL}$ & 1.5 & $0.34-6.8$ \\
\hline $\mathrm{NO}_{3}^{-}$ & $\mu \mathrm{g} \mathrm{km}^{-1}$ & 226 & $113-267$ & 56.5 & $32-352$ & 1.7 & $1.3-2.3$ & $<\mathrm{DL}$ & $<\mathrm{DL}$ & 35 & $26-49$ \\
\hline Phe & $\mu \mathrm{g} \mathrm{km}^{-1}$ & 3.53 & $3.36-4.33$ & 0.125 & $0-0.356$ & $<\mathrm{QL}$ & $0-0.005$ & $<\mathrm{QL}$ & $<\mathrm{QL}$ & $<\mathrm{QL}$ & $0-0.001$ \\
\hline An & $\mu \mathrm{g} \mathrm{km}^{-1}$ & 0.091 & $0.07-0.11$ & 0.013 & $0.01-0.02$ & $<\mathrm{QL}$ & $<\mathrm{QL}$ & $<\mathrm{QL}$ & $<\mathrm{QL}$ & 0.015 & $0-0.015$ \\
\hline Fla & $\mu \mathrm{g} \mathrm{km}^{-1}$ & 0.956 & $0.37-1.27$ & 0.072 & $0.05-0.11$ & $<\mathrm{QL}$ & $<\mathrm{QL}$ & 0.001 & $0-0.002$ & $<\mathrm{QL}$ & $<\mathrm{QL}$ \\
\hline Pyr & $\mu \mathrm{g} \mathrm{km}^{-1}$ & 1.066 & $0.26-1.3$ & 0.110 & $0.03-0.19$ & $<\mathrm{QL}$ & $<\mathrm{QL}$ & 0.003 & $0-0.003$ & $<\mathrm{QL}$ & $0-0.001$ \\
\hline C19 & $\mu \mathrm{g} \mathrm{km}^{-1}$ & 17.4 & $11.5-22.3$ & 4.66 & $3.05-5.66$ & 0.15 & $0-0.16$ & $<\mathrm{QL}$ & $<\mathrm{QL}$ & 0.92 & $0-2.20$ \\
\hline $\mathrm{C} 20$ & $\mu \mathrm{g} \mathrm{km}^{-1}$ & 25.4 & $14.3-29.7$ & 5.10 & $3.36-6.36$ & $<\mathrm{QL}$ & $0-0.27$ & $<\mathrm{QL}$ & $<\mathrm{QL}$ & 2.78 & $0.36-3.25$ \\
\hline $\mathrm{C} 21$ & $\mu \mathrm{g} \mathrm{km}^{-1}$ & 31.5 & $17.1-35.1$ & 5.84 & $3.65-7.65$ & $<\mathrm{QL}$ & $0-1.08$ & $<\mathrm{QL}$ & $<\mathrm{QL}$ & 2.76 & $1.22-4.50$ \\
\hline $\mathrm{C} 22$ & $\mu \mathrm{g} \mathrm{km}^{-1}$ & 22.1 & $13.0-25.8$ & 4.94 & $2.90-6.39$ & $<\mathrm{QL}$ & $<\mathrm{QL}$ & $<\mathrm{QL}$ & $<\mathrm{QL}$ & 2.20 & $0-2.44$ \\
\hline $\mathrm{C} 23$ & $\mu \mathrm{g} \mathrm{km}^{-1}$ & 16.8 & $9.43-21.3$ & 4.18 & $2.23-5.86$ & $<\mathrm{QL}$ & $0-0.85$ & $<\mathrm{QL}$ & $0-0.04$ & 1.11 & $0-1.82$ \\
\hline $\mathrm{C} 24$ & $\mu \mathrm{g} \mathrm{km}^{-1}$ & 11.1 & $6.19-15.1$ & 3.51 & $1.70-4.69$ & 0.13 & $0-0.31$ & $<\mathrm{QL}$ & $<\mathrm{QL}$ & 0.22 & $0-0.70$ \\
\hline $\mathrm{C} 25$ & $\mu \mathrm{g} \mathrm{km}^{-1}$ & 6.12 & $3.00-8.39$ & 1.94 & $1.02-2.87$ & 0.07 & $0-0.53$ & 0.02 & $0.01-0.02$ & $<\mathrm{QL}$ & $<\mathrm{QL}$ \\
\hline $\mathrm{C} 26$ & $\mu \mathrm{g} \mathrm{km}^{-1}$ & 3.57 & $1.91-3.85$ & 1.23 & $0.76-1.56$ & $<\mathrm{QL}$ & $0-0.05$ & $<\mathrm{QL}$ & $0-0.01$ & $<\mathrm{QL}$ & $<\mathrm{QL}$ \\
\hline
\end{tabular}

hicles obtained from chassis dynamometer measurements in our study, for which the highest EFs were clearly observed when vehicles are cold (Fig. 5a). Indeed, these two types of vehicles represented the largest proportion of passenger cars on the RN87 freeway in 2011 (Fallah Shorshani et al., 2015), as well as in the French national fleet. Similarly to the results for diesel vehicles tested by Fujita et al. (2007) and Lough et al. (2007), EC has the highest emission factor in diesel exhaust. It also could be noted that the heavy-duty-traffic-fleet $\mathrm{EF}$ for $\mathrm{EC}$ is about 5 times higher than the one determined for light-duty traffic.

The emissions of OC could not be discriminated between light-duty and heavy-duty traffic (coefficients not significantly different from zero). However, it can be observed that the traffic-fleet EF for OC is larger than could be expected from exhaust measurement of test vehicles (Table 4, Fig. 5b). Note that traffic-fleet EFs for OC from other studies (Handler et al., 2008; Alves et al., 2015; Cui et al., 2016; He et al., 2008) are at least as high as ours, and the EFs for exhaust OC from Cheung et al. (2010) for Euro 4 diesel vehi- cles (with and without a diesel particulate filter) are similar to ours. There are many likely explanations for the trafficfleet EF for OC being higher than expected: proportionally larger contribution of the heavy-duty traffic to OC than to the EC, contribution of non-exhaust emissions to the OC (e.g. tyre wear), contribution of high-emitting vehicles, and rapid formation of secondary OC in the roadside atmosphere. Further studies are required to assess the respective importance of these processes. In particular, a better knowledge of the particle size distribution of OC emitted by traffic might be useful.

Average OC/EC ratios on increments in concentrations and emissions are respectively 0.33 and 0.44 (Table 5) - that is, in excellent agreement with observations in a roadway tunnel in Lisbon and with roadside enrichment of OC/EC in Birmingham, UK (Pio et al., 2011; Alves et al., 2016). Pio et al. (2011) concluded that OC/EC ratios of 0.3-0.4 characterize vehicle fuel combustion at their sites and similar conclusions could be made for Grenoble. However, the OC/EC ratio is expected to depend on vehicle fleet. Indeed, in the ex- 

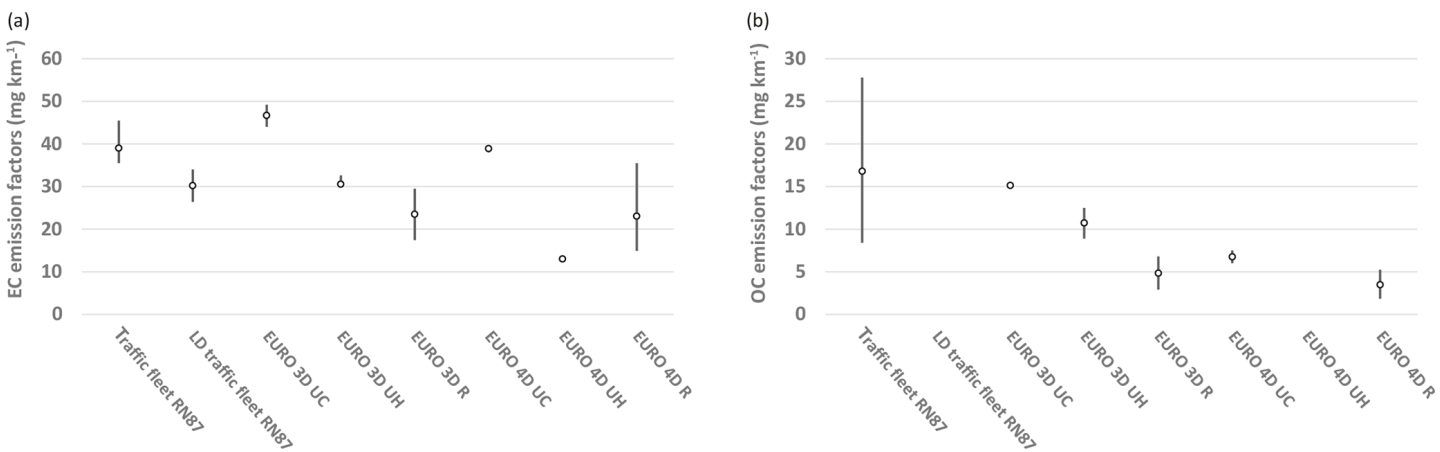

Figure 5. Emission factors for EC (a) and OC (b) for the mixed traffic fleet and the light-duty traffic of the RN87/E712 freeway and from the chassis dynamometer measurements of exhaust emissions of Euro 3 and Euro 4 vehicles for respectively urban cold (UC), urban hot (UH) and road $(\mathrm{R})$ driving cycles. The emission factor for OC for the light-duty-traffic fleet could not be determined and no data are available for the hot driving conditions for the Euro 4 diesel vehicles.

haust of test diesel vehicles without particle filters (Table 4), OC/EC ratios are lower than 0.4 , while they are respectively 6.1 and 1.7 in the exhaust of the Euro 2 petrol vehicle (urban cold cycle) and Euro 4 petrol vehicle (road cycle) (no average OC/EC ratios have been determined for petrol vehicles because of many measurements below the detection limit). Other recent chassis dynamometer measurements (Lough et al., 2007) showed that most OC/EC ratios are above 2 for petrol vehicles (except for two smoker vehicles) and below 0.5 for diesel vehicles (except in idling conditions), with even lower ratios for older and heavier diesel vehicles. Because in 2011 diesel vehicles represented about $70 \%$ of total vehicles on the RN87 highway, the OC/EC ratio found in this study is lower than the ones of many other studies. For examples, $\mathrm{OC} / \mathrm{EC}$ ratios from EFs or increments in concentrations were $0.90 \pm 0.21$ in a tunnel in Austria (Handler et al., 2008) on average 0.52 for a traffic fleet with $40 \%$ diesel vehicles in Spain (Amato et al., 2011a) and 0.5 in Marseille where petrol two-wheelers are much more numerous (El Haddad et al., 2009). However, since the OC/EC ratio in the exhaust of the diesel vehicle equipped with a particle filter was higher (0.7) possibly due to the more efficient trapping of EC than $\mathrm{OC}$ by the particle filter, one can expect that in the future the OC/EC ratio reflecting vehicle fuel combustion would increase with the progressive introduction of vehicles equipped with a particle filter.

\subsubsection{Metals from brake-wear emissions}

Fe presents by far the third highest traffic emission rate after those of EC and OC $\left(6.7 \mathrm{mg} \mathrm{veh}^{-1} \mathrm{~km}^{-1}\right.$, Tables 2). $\mathrm{Cu}$ also shows a high emission factor from traffic (300 $\mu \mathrm{g} \mathrm{veh}^{-1} \mathrm{~km}^{-1}$, respectively). Similarly, major contributions of $\mathrm{Fe}$ and $\mathrm{Cu}$ to $\mathrm{PM}_{10}$ vehicular emissions were found in other locations (e.g. Kam et al., 2012; Harrison et al., 2012). The analysis of brake-wear debris (Apeagyei et al., 2011; Sanders et al., 2003; Kukutschová et al., 2009; Hulskotte et al., 2014) and brake material (Grigoratos and
Martin, 2015; Hulskotte et al., 2014) confirmed that Fe is the major element of brakes and that $\mathrm{Cu}$ is another important element. Indeed, maximum contents of $60 \%$ by mass for $\mathrm{Fe}$ (Grigoratos and Martin, 2015) and of $15 \%$ for $\mathrm{Cu}$ (Denier van der Gon et al., 2007) have been reported for brake lining materials. $\mathrm{Fe}, \mathrm{Cu}, \mathrm{Zn}$ and $\mathrm{Sn}$ would represent about $80 \%-$ $90 \%$ of metals presents in brake pads and $\mathrm{Fe} 95 \%$ of metals in brake discs (Hulskotte et al., 2014).

Our results can be compared with other European traffic EFs determined for $\mathrm{PM}_{10}$ species measured in roadside environments or tunnels and with data derived from average brake-wear composition (details in the Supplement, Sect. VIII). Most $\mathrm{PM}_{10}$ EFs are consistent with other roadside traffic-fleet emissions (Johansson et al., 2009; Bukowiecki et al., 2009) and with data corresponding to braking emissions of $8 \mathrm{mg} \mathrm{veh}^{-1} \mathrm{~km}^{-1}$ (Hulskotte et al. 2014), but they are larger than the estimations aiming to quantify brake wear only (Bukowiecki et al., 2009). Our traffic-fleet $\mathrm{EF}$ for $\mathrm{Sb}$ is much lower than similar EFs determined in other studies, while $\mathrm{Ba}$ emissions show large variability from one study to another. EFs related to brakewear component emissions are lower in tunnel environments (Handler et al., 2008; Alves et al., 2015), except for the oldest study (Gillies et al., 2001). This could be explained by less stop-and-go traffic in such environments. Indeed, interestingly, many EFs determined by Handler et al. (2008) are about half the ones found in this study. Even though this proportionality is not found for $\mathrm{Ba}, \mathrm{Sb}$ and $\mathrm{Ti}$, this shows that brake-wear metal EFs are strongly related with braking strength. The low $\mathrm{Sb}$ emissions of our study may possibly be related to the introduction of Sb-free brake pads (von Uexküll et al., 2005; Apeagyei et al., 2011).

EFs for brake-wear metals $(\mathrm{Cu}, \mathrm{Fe}, \mathrm{Sb}$ and $\mathrm{Sn})$ are 8 to 13 times higher for the heavy-duty traffic than for the lightduty traffic (Table 3). The estimations from Bukowiecki et al. (2009) for brake wear only are much lower than ours but somewhat proportional (factors of 4.6 to 6.8 for light- 
Table 5. Ratios for roadside, incremental (roadside minus urban background) concentrations, and RN87-traffic emission factors, with standard deviations.

\begin{tabular}{lrrrrr}
\hline Ratios on & $\mathrm{Cu} / \mathrm{Sb}$ & $\mathrm{Cu} / \mathrm{Fe}$ & $\mathrm{Cu} / \mathrm{Sn}$ & $\mathrm{Cu} / \mathrm{Mn}$ & $\mathrm{OC} / \mathrm{EC}$ \\
\hline Roadside concentrations & $10.4 \pm 4.5$ & $0.045 \pm 0.015$ & $4.7 \pm 1.0$ & $3.6 \pm 1.6$ & $1.00 \pm 0.49$ \\
Incremental concentrations & $11.7 \pm 5.1$ & $0.043 \pm 0.015$ & $5.4 \pm 1.8$ & $6.4 \pm 5.9$ & $0.33 \pm 0.22$ \\
LDV emission factors & $12.8 \pm 5.2^{\mathrm{a}}$ & $0.041 \pm 0.010^{\mathrm{a}}$ & $4.8 \pm 1.1^{\mathrm{a}}$ & und. & und. \\
HDV emission factors & $13.7 \pm 4.3^{\mathrm{a}}$ & $0.070 \pm 0.017^{\mathrm{a}}$ & $6.6 \pm 1.1^{\mathrm{a}}$ & und. & und. \\
Traffic emission factors & $12.6 \pm 4.7$ & $0.046 \pm 0.015$ & $5.6 \pm 1.8$ & $5.7 \pm 2.9$ & $0.44 \pm 0.32$ \\
\hline \multirow{2}{*}{ Using Taylor expansion for approx. $\operatorname{var}\left(\frac{x}{y}\right)=\frac{1}{\mu_{y}^{2}} \operatorname{var}(x)+\frac{\mu_{x}^{2}}{\mu_{y}^{4}} \operatorname{var}(y)-2 \frac{\mu_{x}}{\mu_{x}^{3}} \operatorname{Cov}(x y)}$. & & &
\end{tabular}

duty EFs and from 4.3 to 8.5 for the heavy-duty traffic $\mathrm{Sb}$ excluded). This consistency between brake profiles suggests that brake compositions would be similar in different European countries. Traffic-fleet light-duty EFs for brakewear metals are much higher than the ones from chassis dynamometer exhaust measurements (this study: Table 4; Cheung et al., 2010), confirming the dominant contribution of braking for these elements.

The sum of traffic-fleet EFs for metals related to brake wear (Ba, Cr, Cu, Fe, Mn, Sb, Sn, Ti - Table 2b) leads to a total of $7.3 \mathrm{mg} \mathrm{km}^{-1}$ that should be lower than the real emission factors for brake-wear dusts since the sum of traffic fleet EFs for metals only includes metals and does not take into account carbonaceous material and other unquantified compounds of brakes ( $\mathrm{S}, \mathrm{Zn}, \mathrm{Al}$ and $\mathrm{Si}$, for the most important ones). Hulskotte et al. (2014) determined a brake profile from the analysis of 65 brake pads and 15 brake discs from eight very common car brands in Europe. The consistency between with their data and ours suggests that brakes spent in France are quite similar to the ones spent in the Netherlands. Then, their average brake profile data are used to estimate the average emission factor for brake wear assuming that the total proportion of metals is kept and, according to Hulskotte et al. (2014), that $70 \%$ of the wear arises from the disc. This latter assumption is supported by other researches (Sander et al., 2003; Varrica et al., 2013), even though the generation mechanisms of brake-wear particles have not been fully understood yet (Grigoratos and Martini, 2014). Since exhaust emissions (chassis dynamometer measurements or EFs from the COPCETE inventory when available) represent less than $5 \%$ of total emissions for $\mathrm{Cr}, \mathrm{Cu}, \mathrm{Fe}, \mathrm{Mn}, \mathrm{Sb}, \mathrm{Sn}$ and $\mathrm{Ti}$, traffic-fleet EFs for these elements are assumed to be entirely due to the emissions of brake-wear dusts. So by adding the portion that corresponds to the elements and compounds not quantified in this study $(\mathrm{C}, \mathrm{S}, \mathrm{Zn}, \mathrm{Al}, \mathrm{Si}, \mathrm{Zr}, \mathrm{Mo}, \mathrm{V}, \mathrm{Ni}, \mathrm{Bi}, \mathrm{W}$, $\mathrm{P}, \mathrm{Pb}, \mathrm{Co}$ ) to the sum of traffic-fleet $\mathrm{EFs}$ for metals related to brake wear, the rough estimation of $9.2 \mathrm{mg} \mathrm{km}^{-1}$ for emissions related to brake wear is retrieved for the RN87 highway traffic. This estimation includes particles directly emitted during braking and those resuspended, as well as emissions from light- and heavy-duty traffic. It should be highlighted that this EF for brake-wear emissions is almost twice the particle emission standards for the exhausts of the most recent vehicles (Euro 5 and Euro 6 vehicles, $5 \mathrm{mg} \mathrm{km}^{-1}$ ).

According to inventories atmospheric copper is largely from brake wear. Indeed brake wear represents $50 \%-75 \%$ of European $\mathrm{Cu}$ emissions (Denier Van der Gon et al., 2007) and $64 \%$ of French $\mathrm{Cu}$ emissions (CITEPA, 2018). Since $\mathrm{Sb}$ is another well-known constituent of brake with very few other atmospheric sources, the $\mathrm{Cu} / \mathrm{Sb}$ ratio was often considered as a candidate to trace brake-wear emissions (Gietl et al., 2010; Pant and Harrison, 2013). Pant and Harrison (2013) reviewed $\mathrm{Cu} / \mathrm{Sb}$ ratios in brake-wear particles and found ratios from 1.3 to 9.1 that strongly depend on the PM size fraction. The estimation for the $\mathrm{Cu} / \mathrm{Sb}$ ratio $(11.7 \pm 5.1$ for incremental $\left.\mathrm{PM}_{10}\right)$ is close to the ones for $\mathrm{PM}_{10}$ elemental concentrations in other European locations including London, UK (on average 9.1, Gietl et al., 2010); Barcelona, Spain (7.0-7.9, Amato et al., 2011a); Bern and Zurich, Switzerland (respectively 13.2 and 8.5, Hueglin et al., 2005); and in road dust below $10 \mu \mathrm{m}$ collected in Barcelona, Zurich and Girona (respectively $6.8 \pm 0.9,13.5 \pm 6.1,17.0 \pm 8.9$, Amato et al., 2011b). However, lower $\mathrm{PM}_{10} \mathrm{Cu} / \mathrm{Sb}$ ratios are found for other $\mathrm{Eu}-$ ropean traffic sites, in Sweden $(4.6 \pm 2.3$, Sternbeck et al., 2002 and 3.8, Johansson et al., 2009); in Portugal (about 2, Alves et al., 2015); and in Vienna, Austria (1.6, Handler et al., 2008). To complicate the matter further, published data from the analysis of brake pads and discs are even more scattered, roughly from 1.3 to 2000 (Adachi and Tainosho, 2004; Canepari et al., 2008; Ijima et al., 2007), and often different than the chemical composition of brake-wear particles (Grigoratos and Martini, 2015). The poorer relationship between $\mathrm{Cu}$ and $\mathrm{Sb}$ (Pearson $r^{2}=0.4$ ) than those observed between $\mathrm{Sn}, \mathrm{Cu}$ and $\mathrm{Fe}$ (Pearson $r^{2}>0.8$ ) and the lower EF for Sb of this study than observations at other sites may be explained by the introduction of Sb-free brake pads. Thus, while the occurrence of $\mathrm{Sb}$ may be largely explained by braking activities, the use of a typical factor for braking activities using $\mathrm{Sb}$ seems to be less obvious.

The very strong linear relationships found between $\mathrm{Fe}, \mathrm{Cu}$, $\mathrm{Mn}$ and Sn with no significant intercept (virtually equal to zero) suggest that ratios including these compounds are also worthy of attention. Even though $\mathrm{Fe}$ is much less specific of brake-wear emissions than $\mathrm{Cu}$ or Sb, Hulskotte et al. (2014) 
observed a stable $\mathrm{Cu} / \mathrm{Fe}$ ratio of about $4 \%$ in different $\mathrm{Eu}-$ ropean kerbside locations (the Netherlands: Boogaard et al., 2011; England: Gietl et al., 2010; Switzerland: Hueglin et al., 2005). They concluded that brake wear is probably the single source of both copper and iron in urban aerosols. The review of other recent studies leads to similar conclusions. Pio et al. (2013) determined an average $\mathrm{Fe} / \mathrm{Cu}$ ratio of 21 (and then $\mathrm{Cu} / \mathrm{Fe}=0.048$ ) from tunnel and busy road measurements in Portugal. $\mathrm{Cu} / \mathrm{Fe}$ ratios at two traffic sites in Barcelona ranged from 0.034 to 0.058 (Amato et al., 2011a). Except for the site of Weerdsingel in Utrecht, $\mathrm{Cu} / \mathrm{Fe}$ ratios calculated from average $\mathrm{PM}_{10}$ elemental concentrations measured at eight street locations in the Netherlands also ranged from 0.039 to 0.048 (Boogaard et al., 2011). Only Alves et al. (2015) found a much higher $\mathrm{Cu} / \mathrm{Fe}$ ratio in $\mathrm{PM}_{10}$ collected in a tunnel in Portugal mainly due to a very low EF for $\mathrm{Cu}$ compared to other studies. The $\mathrm{Cu} / \mathrm{Fe}$ ratio determined in our study for light-duty traffic $(0.041 \pm 0.010)$ is very similar to the ones found in the majority of these European roadside sites (Table 5), while the ratio determined for the heavy-duty traffic $(0.070 \pm 0.017)$ is slightly larger due to proportionally higher emissions of $\mathrm{Cu}$. Again, this suggests that brake materials used in different European countries are very similar and that the $\mathrm{Cu} / \mathrm{Fe}$ ratio could be used as an indication of brake-wear emissions.

Ratios with $\mathrm{Mn}$ and $\mathrm{Sn}$ are more rarely discussed in the literature, and published information is scarce. $\mathrm{Cu} / \mathrm{Sn}$ ratios of 6.2 and 4.3 can be calculated from data published by Handler et al. (2008) and Johansson et al. (2009), respectively. Amato et al. (2011a) found a $\mathrm{Cu} / \mathrm{Sn}$ ratio that ranged from 4.7 to 4.8 and did not estimate ratios with Mn because of the possible influence of a local steel source. $\mathrm{Cu} / \mathrm{Mn}$ ratios of 3.7, 4.9 and 3.0 (Bern) as well as 4.4 (Zurich) are respectively calculated from the studies of Handler et al. (2008), Johansson et al. (2009) and Hueglin et al. (2005). All these ratios are close to the ones of this study $(\mathrm{Cu} / \mathrm{Sn}=4.1 \pm 1.0$; $\mathrm{Cu} / \mathrm{Mn}=3.6 \pm 1.6$, Table 5), showing that they are possible candidates to trace brake-wear emissions. $\mathrm{Cu} / \mathrm{Sn}$ would be the strongest candidate since the relation between these two elements is closer $\left(r^{2}=0.84\right.$ for $\mathrm{Cu} / \mathrm{Sn}$ vs. $r^{2}=0.47$ for $\mathrm{Cu} / \mathrm{Mn}$; see Supplement).

\subsubsection{Emissions of organic markers of diesel exhaust and lubricating oil}

As previously observed (Schauer et al., 2002; Perrone et al., 2014; El Haddad et al., 2009), n-alkanes are abundant organic compounds of total quantified organic compounds emitted by vehicles on road.

In agreement with other chassis dynamometer measurements (Rogge et al., 1993a; Cheung et al., 2010; Perrone et al., 2014; Cui et al., 2017), the most important $n$-alkanes in diesel exhaust emissions are $\mathrm{C} 19$ to $\mathrm{C} 26$, while most emissions were below the detection limit for the two petrol vehicles (Table 4). Schauer et al. (2002) showed that $n$-alkanes are present in particulate exhaust emissions of non-catalystequipped petrol vehicles, but they are almost absent in the exhaust of catalyst-equipped petrol motor vehicles. In 2011 virtually all petrol vehicles were catalyst-equipped (Fallah Shorshani et al., 2015). C19-C26 n-alkanes are also the most important in roadside increments in concentration, and as a further indication of road traffic contribution, the carbon preference index (CPI; for calculation see Supplement Sect. VI) is very close to unity (0.99), indicating equal distribution between odd and even carbon number typical of anthropogenic emissions (Harrad et al., 2003; Cincinelli et al., 2007; Kam et al., 2012; Alves et al., 2016). Light-duty-traffic EFs for C23 and C24 are in agreement with the ones of the Euro 3 diesel vehicle from chassis dynamometer measurements (upper range) and with the ones determined by Perrone et al. (2014) for Euro 3 diesel vehicles (C23: $16.3 \mu \mathrm{g} \mathrm{km}^{-1}$; C24: $12.7 \mu \mathrm{g} \mathrm{km}^{-1}$ ). Good agreements are also found for C25 and C26. However, the traffic EF determined by Perrone et al. (2014) for C21 is half of the one of this study, and the one for $\mathrm{C} 20$ is one-fifth of the one of this study. All EFs determined by Perrone et al. (2014) for Euro 4 diesel vehicles are larger than the ones of the Euro 4 diesel vehicle of this study but of similar magnitude.

The relative contributions of the $n$-alkane series in diesel exhaust show Gaussian-like shapes peaking between C20 and C22 (Rogge et al., 1993a; Morawska and Zhang, 2002; El Haddad et al., 2009; Cheung et al., 2010; Fujitani et al., 2012; Perrone et al., 2014; Cui et al., 2017). In this study, the dominant alkanes are $\mathrm{C} 21$ in the exhaust of test diesel vehicles and C22 in traffic RN87 emissions (Fig. 6). Fujitani et al. (2012) showed that shifts from C20 to C22 and differences between real-atmosphere measurements and exhaust measurements are entirely explained by gas-to-particle partitioning at different dilution ratios (dominant $n$-alkanes were $\mathrm{C} 20$ and $\mathrm{C} 22$ at dilution ratios of 14 and 238, respectively). Accordingly, in this study, $\mathrm{C} 21$ is the dominant $n$-alkane at diesel exhaust dilution ratios of about 80; and a shift toward a heavier $n$-alkane has been observed in the roadside atmosphere. $n$-Alkanes normalized by OC ( $\mu \mathrm{g} \mathrm{g}^{-1}$ ) (Fig. 6) show values for Euro 3 and Euro 4 diesel emissions as well as RN87 traffic emissions that are about half of the values measured in a tunnel in Marseille (El Haddad et al., 2009). Much higher values are found with the vehicle retrofitted with a particle filter (Fig. 6). These high values are due to very low OC emissions by the vehicle equipped with a particle filter and clearly show less effective reduction of $n$-alkanes than total OC. Because of their semi-volatile nature, $n$-alkanes may pass the particle filter in their gaseous phase at higher temperatures. While the $n$-alkane series from $\mathrm{C} 19$ to $\mathrm{C} 26$ peaking around C20-C22 seems to be characteristics of diesel emissions, an increase in the $n$-alkane / OC values could be expected for the future.

Low-molecular-weight PAHs (An, Fla, Pyr) are frequently associated with particulate diesel exhaust emissions (e.g. Kleeman et al., 2008; Keyte et al., 2016). Accordingly, both 

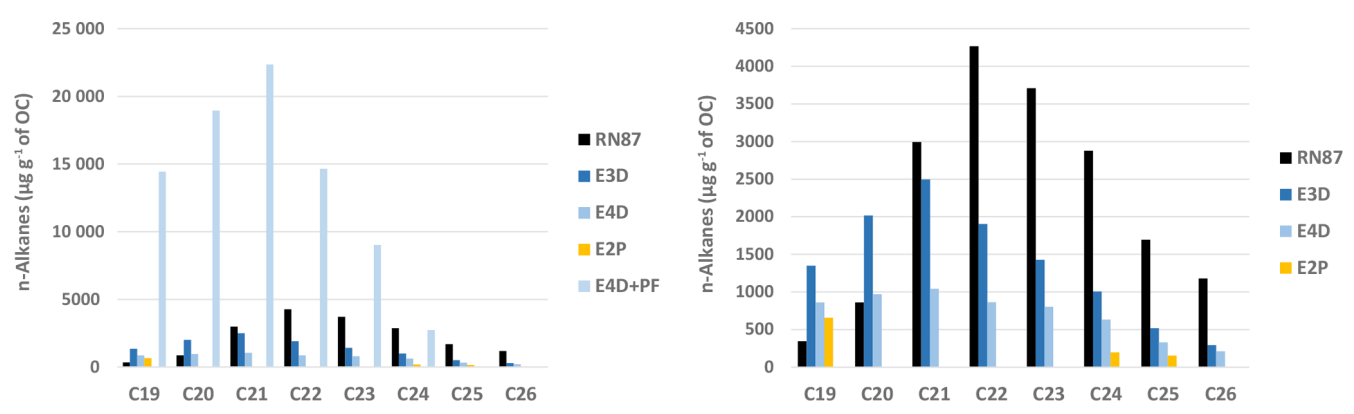

Figure 6. $n$-Alkane emissions normalized by OC emissions at the traffic site (RN87/E712) and from the exhaust of a diesel Euro 3 vehicle (E3D), a diesel Euro 4 vehicle (E4D), a diesel Euro 4 vehicle equipped with a particle filter (E4D + PF) (on the left only) and a Euro 2 petrol vehicle.

chassis dynamometer and in situ measurements indicate that diesel vehicles are a major source of these chemical species. Indeed, they are almost absent in petrol exhaust emissions and are strongly related to RN87 traffic emissions. EFs for PAHs determined for the heavy-duty traffic are much higher than the ones determined for light-duty traffic: from 6 times higher for Fla up to 20 times higher for Pyr (Table 3). High emissions of Pyr by heavy-duty vehicles have already been observed anywhere else (Liacos et al., 2012; Cui et al., 2017). While the comparison between EFs determined during different conditions is not straightforward in the absence of gas-phase measurements due to the high vapour pressure of the lowest-molecular-weight organics (Fujitani et al., 2012; Polo-Rehn, 2013), quite good agreements are found between chassis dynamometer measurements and traffic EFs and with data from other studies. Indeed, again the light-duty-traffic EFs for Fla and Pyr are quite consistent with the ones of the diesel Euro 3 measured with the chassis dynamometer. The light-duty-traffic EF for An is proportionally lower, somewhere between the ones of test Euro 3 and Euro 4 vehicles. The average EF for Pyr for the Euro 3 diesel vehicle of this study (Table 4) is close to the ones of Perrone et al. (2014) for Euro 3 diesel vehicles $\left(740 \pm 300 \mathrm{ng} \mathrm{km}^{-1}\right.$ for passenger cars and $1810 \pm 570 \mathrm{ng} \mathrm{km}^{-1}$ for commercial utility vehicles). Traffic EFs for Fla and Pyr are also in good agreement with average EFs in a tunnel in China (tunnel traffic details: 40$50 \mathrm{~km} \mathrm{~h}^{-1}$; 784-2776 veh h ${ }^{-1} ; 18.4 \%-35.1 \%$ HDVs; see He et al., 2008). These satisfying agreements suggest that EFs determined in this research may be quite well representative of in-use vehicles. However, gas-particle partitioning and photochemical degradation processes may make the use of quantitative data for these markers difficult, as already observed (Zhang et al., 2005; Phuleria et al., 2007; Katsoyiannis et al., 2011; Tobiszewski and Namieśnik, 2012).

In agreement with previous observations (Phuleria et al., 2006, 2007; He et al., 2008; El Haddad et al., 2009; Alves et al., 2016; Pant et al., 2017), 17 $\alpha, 21 \beta$-norhopane and $17 \alpha, 21 \beta$-hopane are the two dominant hopanes associated with traffic emissions. Very few traffic EFs are available for hopanes in the recent literature and most data available from recent studies are related to fuel consumption (e.g. Phuleria et al., 2006, 2007). Traffic hopane EFs of this study are much lower than those computed for tunnels in China (He et al., 2008; Cui et al., 2016). In order to compare with European tunnel data, traffic EFs are normalized by OC emissions. The normalized abundance of $17 \alpha, 21 \beta$-norhopane ( $246 \mu \mathrm{g}$ per $\mathrm{g}$ of OC) is similar to the one for a tunnel in Lisbon (Alves et al., 2016) but almost half the ones for tunnels in Marseille and Birmingham (El Haddad et al., 2009; Pant et al., 2017). Conversely, the value for $17 \alpha, 21 \beta$-hopane (301 $\mu \mathrm{g}$ per $\mathrm{g}$ of OC) is very close to the ones found in tunnels in Birmingham and Marseille but twice the one for the tunnel in Lisbon. These divergences and the quantification of heavy-dutytraffic emissions require further work in order to be able to define specific EFs and normalized abundances for hopanes.

\subsubsection{Other non-exhaust emissions}

The average traffic-fleet $\mathrm{EFs}$ for $\mathrm{Ca}^{2+}$ is the fifth highest traffic-fleet emission factor after $\mathrm{EC}, \mathrm{OC}, \mathrm{Fe}$ and $\mathrm{NO}_{3}^{-}$. While the emissions of $\mathrm{Ca}^{2+}$ could not be discriminated between light-duty and heavy-duty traffic (autocorrelation), this much larger emission factor than the ones measured in the exhaust of diesel vehicles is in agreement with its origin. If $\mathrm{Ca}^{2+}$ mainly comes from road dust resuspension, it does not only depend on the intensity of traffic but also on the amounts of calcium deposited on the road (silt loading). Bukowiecki et al. (2009) used the mass concentration measured $1 \mathrm{~h}$ earlier in order to empirically account for the observed autocorrelation behaviour in the calcium time series due to the accumulation of resuspended dust. The time series resolution of $4 \mathrm{~h}$ for collected particles in this study does not allow such calculations. Note that contrary to Bukowiecki et al. (2009) most other trace elements that could be regressed in this study do not have the same behaviour as $\mathrm{Ca}^{2+}$. This could be explained by the removal of road dusts thanks to frequent rain events before and during the sampling period.

Since EU tyres contain about $1 \%$ zinc oxide (Pant and Harrison, 2013) and $\mathrm{Zn}$ is the most abundant metallic element in tyres commercialized in the US (Apeagyei et al., 
2011), $\mathrm{Zn}$ is often proposed as a key tracer of tyre wear emissions. In this study, similarly to other works (Boogaard et al., 2011; Amato et al., 2011a), Zn concentrations did not show any roadside increment. This suggests the prevalence of other sources of $\mathrm{Zn}$ in the Grenoble Alpes conurbation, as well as in other urban environments. Further research is needed to determine proper tracers of tyre wear emissions.

\section{Conclusions}

Thanks to a very large comprehensive dataset of particulate species collected from a simultaneous near-road and urban background measurement field campaign and chassis dynamometer experiments of a few in-use passenger cars, this study was able to determine emission factors for many particulate species from road traffic and to identify and quantify tracers of exhaust and non-exhaust vehicular emissions that could be used in source apportionment studies. Nearroad measurements are made near a freeway with various driving conditions from free-flowing to stop-and-go traffic, including frequent and severe braking events during periods of congestion (morning and afternoon commuting times of workdays).

EC has the highest traffic emission factors and is strongly associated with diesel traffic. The emission factor for EC for the light-duty traffic is similar to the ones of passenger diesel cars without particle filters. EC emissions from heavy-duty vehicles are estimated to be 5 times higher than those for light-duty vehicles. The traffic-fleet EF for OC is slightly larger than those deduced from exhaust measurement of test vehicles. This later observation would require further investigations in order to delineate the several possible causes for such observation. The determination of the particle size distribution of OC could improve knowledge of the organic emissions of traffic. In this environment dominated by the diesel traffic, the OC/EC ratio is below 0.4 (increments in concentration or emissions), as it is in diesel exhaust emissions. However, this ratio depends on the traffic fleet and then may change in the future with the progressive introduction of vehicles retrofitted with a particle filter.

Results showed the important contribution of metals from brake wear to particulate vehicular emissions. In particular, Fe has the third highest traffic emission factor after EC and OC. Total brake-wear emissions are estimated for the RN87 highway: they are on average almost twice the particle emission standards for the exhausts of newer vehicles (from Euro 5). We have shown that $\mathrm{Cu}$ is another important contributor to $\mathrm{PM}_{10}$ from traffic, and it could be an excellent tracer of brake-wear emissions in most environments. Even though they are less specific than $\mathrm{Cu}$, other metals such as $\mathrm{Fe}$ and $\mathrm{Sn}$ may be used to trace brake-wear emissions through typical ratios. In particular, $\mathrm{Cu} / \mathrm{Fe}$ ratios of about 0.041 for lightduty traffic may possibly be the best option for estimating the brake-wear emissions due to the traffic of European pas- senger cars. $\mathrm{Cu} / \mathrm{Fe}$ ratios in agreement with literature values for other kerbside sites, while $\mathrm{Cu} / \mathrm{Fe}$ ratios may be different for urban background or rural sites (e.g. Hueglin et al., 2005; this study: Les Frênes' data), suggest similar brake composition for these elements throughout Europe (as long as $\mathrm{Cu}$ free brakes do not increase in use). Our measurements support more the use of $\mathrm{Cu} / \mathrm{Sn}$ than that of $\mathrm{Cu} / \mathrm{Mn}$ and $\mathrm{Cu} / \mathrm{Sb}$ as tracers of brake-wear emissions possibly due to an additional source of $\mathrm{Mn}$ and the introduction of Sb-free brake pads. Similarly to OC, the determination of the particle size distribution of metals may possibly improve the discrimination between influential sources in urban areas.

Particulate organic emission data for European motor vehicles are scarce. In this study, a few PAHs, $n$-alkanes and hopanes have been identified as organic molecular markers of fresh diesel traffic emissions, and their emission factors have been quantified. In agreement with previous works, low-molecular-weight PAHs (mainly An, Fla, Pyr) are associated with diesel exhaust emissions. Pyrene and fluoranthene are the ones that are most strongly associated with fresh diesel exhaust emissions. Pyrene is largely emitted by the heavy-duty traffic. Similarly to PAHs, $n$-alkanes from C19 to C26 are also associated with diesel vehicles, even though the determination of the concentration of the dominant alkanes (from C20 to C23) strongly depends on measurement conditions. While the comparison with other recent studies can be difficult in the absence of gas quantification for in situ measurements, a quite good agreement is found for most organics between chassis dynamometer and near-road measurements and between this study and other recent studies. However, the change in the gas-particle partitioning of low molecular PAHs and $n$-alkanes according to ambient temperature and dilution factors, and their possible short-term photochemical degradation, may compromise their use as quantitative markers of fuel combustion.

Hopanes are markers of lubricating oil in the emissions of high-emitting vehicles (Rogge et al., 1993a; Zielinska et al., 2004). In this study two hopanes $(17 \alpha, 21 \beta$-norhopane and $17 \alpha, 21 \beta$-hopane) have been clearly associated with the traffic and more closely related to the heavy-duty traffic. However the quantification of ratios of hopanes to OC showed divergences with other studies that require a better understanding.

This study determines many quantitative data of traffic exhaust and non-exhaust emissions that could help in a better definition of traffic emissions in source apportionment studies.

Data availability. Data are available upon request.

Supplement. The supplement related to this article is available online at: https://doi.org/10.5194/acp-19-5187-2019-supplement. 
Author contributions. AC was responsible for the design and coordination of the PM-DRIVE project and the data analyses and designed the vehicle experiments. JLJ, JLB and NM contributed to the design of the PM-DRIVE project. CB was responsible for the design and coordination of the MOCOPO project and designed the traffic measurements. JLJ was responsible for the field experiments and PM analyses (metals, ions, EC, OC). JLB was responsible for organic speciation. HC and GG were responsible for regulated PM and gas sampling. LPR and BG contributed to field measurements, $\mathrm{PM}$ analyses and interpretation of data. The paper was prepared by AC. JLJ, JLB, BG, LPR, NM and CB contributed to the interpretation of the results and discussions on the paper.

Competing interests. The authors declare that they have no conflict of interest.

Acknowledgements. This work was funded by CORTEA-ADEME (PM-DRIVE program 1162C0002), which includes the funding of chassis dynamometer and near-road field and urban background campaigns, and PREDIT (MOCOPO program), which includes the near-road field measurements of regulated pollutants and traffic characteristics. Lucie Polo-Rehn's PhD was funded by the Région Rhône-Alpes. Rain data were supplied by Météo France. The authors would like to thank Patrick Tassel, Pascal Perret and Mathieu Goriaux (chassis dynamometer experiments) as well as Julie Cozic and Jean-Charles Francony (sample analyses) for their contribution to this work. We also thank Michel André for supplying COPCETE emission factors. Part of the chemical analysis was performed on equipment provided by Labex OSU@2020 (ANR10 LABX56).

Edited by: Sally E. Pusede

Reviewed by: two anonymous referees

\section{References}

Adachi, K. and Tainosho Y.: Characterization of heavy metals particles embedded in tire dust, Environ. Int., 30, 1009-1017, 2004.

Alves, C. A., Gomes, J., Nunes, T., Duarte, M., Calvo, A., Custodio, D., Pio, C., Karanasiou, A., and Querol, X.: Size-segregated particulate matter and gaseous emissions from motor vehicles in a road tunnel, Atmos. Res., 153, 134-144, 2015.

Alves, C. A., Oliveira, C., Martins, N., Mirante, F., Caseiro, A., Pio, C., Matos, M., Silva, H. F., Oloveira, C., and Camões, F.: Road tunnel, roadside, and urban background measurements of aliphatic compounds in size-segregated particulate matter, Atmos. Res., 168, 139-148, 2016.

Amato, F., Viana, M., Richard, A., Furger, M., Prévôt, A. S. H., Nava, S., Lucarelli, F., Bukowiecki, N., Alastuey, A., Reche, C., Moreno, T., Pandolfi, M., Pey, J., and Querol, X.: Size and time-resolved roadside enrichment of atmospheric particulate pollutants, Atmos. Chem. Phys., 11, 2917-2931, https://doi.org/10.5194/acp-11-2917-2011, 2011a.

Amato, F., Pandolfi, M., Moreno, T., Furger, M., Pey, J., Alastuey, A., Bukowiecki, N., Prévôt, A. S. H., Baltensperger, U., and Querol, X.: Source and variability of inhalable road dust parti- cles in three European cities, Atmos. Environ., 11, 6777-6787, 2011b.

Amato, F., Casse, F. R., Denier van der Gon, H. A. C., Gehrig, R., Gustafsson, M., Hafner, W., Harrison, R. M., Jozwicka, M., Kelly, F. J., Moreno, T., Prevot, A. S. H., Schaap, M., Sunyer, J., and Querol, X.: Urban air quality: The challenge of traffic nonexhaust emissions, J. Hazard. Mat., 275, 31-36, 2014.

André, M.: The ARTEMIS European driving cycles for measuring car pollutant emissions, Sci. Total Environ., 334-335, 73-84, 2004.

Apeagyei, E., Bank, M. S., and Spengler, J. D.: Distribution of heavy metals in road dust along an urban-rural gradient in Massachusetts, Atmos. Environ., 45, 2310-2323, 2011.

Aymoz, G., Jaffrezo, J. L., Chapuis, D., Cozic, J., and Maenhaut, W.: Seasonal variation of $\mathrm{PM}_{10}$ main constituents in two valleys of the French Alps. I: EC/OC fractions, Atmos. Chem. Phys., 7, 661-675, https://doi.org/10.5194/acp-7-661-2007, 2007.

Beelen, R., Raaschou-Nielsen, O., Stafoggia, M., Andersen, Z. J., Weinmayr, G., Hoffmann, B., Wolf, K., Samoli, E., Fischer, P., Nieuwenhuijsen, M., Vineis, P., Xun, W. W., Katsouyanni, K., Dimakopoulou, K., Oudin, A., Forsberg, B., Modig, L., Havulinna, A. S., Lanki, T., Turunen, A., Oftedal, B., Nystad, W., Nafstad, P., De Faire, U., Pedersen, N. L., Ostenson, C. G., Fratiglioni, L., Penell, J., Korek, M., Pershagen, G., Eriksen, K. T., Overvad, K., Ellermann, T., Eeftens, M., Peeters, P. H., Meliefste, K., Wang, M., Bueno-de-Mesquita, B., Sugiri, D., Kramer, U., Heinrich, J., de Hoogh, K., Key, T., Peters, A., Hampel, R., Concin, H., Nagel, G., Ineichen, A., Schaffner, E., ProbstHensch, N., Kunzli, N., Schindler, C., Schikowski, T., Adam, M., Phuleria, H., Vilier, A., Clavel-Chapelon, F., Declercq, C., Grioni, S., Krogh, V., Tsai, M. Y., Ricceri, F., Sacerdot, C., Galassi, C., Migliore, E., Ranzi, A., Cesaroni, G., Badaloni, C., Forastiere, F., Tamayo, I., Amiano, P., Dorronsoro, M., Katsoulis, M., Trichopoulou, A., Brunekreef, B., and Hoek, G.: Effects of long-term exposure to air pollution on natural-cause mortality: an analysis of 22 European cohorts within the multicentre ESCAPE project, Lancet, 383, 785-795, https://doi.org/10.1016/s01406736(13)62158-3, 2014.

Boogaard, H., Kos, G. P. A., Weijers, E. P., Janssen, N. A. H., Fischer, P. H., van der Zee, S. C., de Hartog, J. J., and Hoek, G.: Contrast in air pollution components between major streets and background locations: Particulate matter mass, black carbon, elemental composition, nitrogen oxide and ultrafine particle number, Atmos. Environ. 45, 650-658, 2011.

Bukowiecki, N., Lienemann, P., Hill, M., Figi, R., Richard, A., Furger, M., Rickers, K., Falkenberg, G., Zhao, Y., Cliff, S. S., Prévôt, A. S. H., Baltensperger, U., Buchmann, B., and Gehrig, R.: Real-world emission factors for antimony and other brake wear related trace elements: size-segregated values for light and heavy duty vehicles, Environ. Sci. Technol., 43, 8072-8078, 2009.

Canepari, S., Perrino, C., Olivieri, F., and Astolfi, M. L.: Characterisation of the traffic sources of PM through size-segregated sampling, sequential leaching and ICP analysis, Atmos. Environ., 42, 8161-8175, 2008.

Cassee, F. R., Héroux, M.-E., Gerlofs-Nijland, M. E., and Kelly, F. J.: Particulate matter beyond mass: recent health evidence on the role of fractions, chemical constituents and sources of emission, Inhal. Toxicol. 25, 802-812, 2013. 
Cavalli, F., Viana, M., Yttri, K. E., Genberg, J., and Putaud, J.-P.: Toward a standardised thermal-optical protocol for measuring atmospheric organic and elemental carbon: the EUSAAR protocol, Atmos. Meas. Tech., 3, 79-89, https://doi.org/10.5194/amt-3-792010, 2010 .

Charron, A. and Harrison, R. M.: Fine $\left(\mathrm{PM}_{2.5}\right)$ and coarse $\left(\mathrm{PM}_{2.5-10}\right)$ particulate matter on a heavily trafficked London highway: sources and processes, Environ. Sci. Technol., 39, 7768-7776, https://doi.org/10.1021/es050462i, 2005.

Cheng, M. H., Chiu, H. F., and Yang, C. Y.: Coarse particulate air pollution associated with increased risk of hospital admissions for respiratory diseases in a Tropical city, Kaohsiung, Taiwan, Int. J. Environ. Res. Public Health, 12, 13053-13068, https://doi.org/10.3390/ijerph121013053, 2015.

Cheung, K. L., Ntziachristos, L., Tzamkiozis, T., Schauer, J. J., Samaras, Z., Moore, K. F., and Sioutas, C.: Emissions of Particulate Trace Elements, Metals and Organic Species from Gasoline, Diesel, and Biodiesel Passenger Vehicles and Their Relation to Oxidative Potential, Aerosol Sci. Technol., 44, 500-513, https://doi.org/10.1080/02786821003758294, 2010.

Cincinelli, A., Del Bubba, M., Martellini, T., Gambaro, A., and Lepri, L.: Gas-particle concentration and distribution of $\mathrm{n}$ alkanes and polycyclic aromatic hydrocarbons in the atmosphere of Prato (Italy), Chemosphere 68, 472-478, 2007.

CITEPA, édition mars: Inventaire des émissions de polluants atmosphériques en France métropolitaine, format CEE-NU, available at: https://www.citepa.org/images/III-1_Rapports_Inventaires/ CEE-NU/UNECE_France_mars2018.pdf (last access: March 2019), 2018.

Cui, M., Chen, Y., Tian, C., Zhang, F., Yan, C., and Zheng, M.: Chemical composition of $\mathrm{PM}_{2.5}$ from two tunnels with different fleet characteristics, Sci. Total Environ., 550, 123-132, 2016.

Cui, M., Chen, Y., Feng, Y., Li, C., Zheng, J., Tian, C., Yan, C., and Zheng, M.: Measurement of PM and its chemical composition in real-world emissions from non-road and onroad diesel vehicles, Atmos. Chem. Phys., 17, 6779-6795, https://doi.org/10.5194/acp-17-6779-2017, 2017.

Denier Van der Gon, H. A. C., Hulskotte, J. H. J., Visschedijk, A. J. H., and Schaap, M.: A revised estimate of copper emissions from road transport in UNECE Europe and its impact on predicted copper concentrations, Atmos. Environ., 41, 8697-8710, 2007.

DeWitt, H. L., Hellebust, S., Temime-Roussel, B., Ravier, S., Polo, L., Jacob, V., Buisson, C., Charron, A., André, M., Pasquier, A., Besombes, J. L., Jaffrezo, J. L., Wortham, H., and Marchand, N.: Near-highway aerosol and gas-phase measurements in a high-diesel environment, Atmos. Chem. Phys., 15, 4373-4387, https://doi.org/10.5194/acp-15-4373-2015, 2015.

El haddad, I., Marchand, N., Dron, J., Temime-Roussel, B., Quivet, E., Wortham, H., Jaffrezo, J. L., Baduel, C., Voisin, D., Besombes, J. L., and Gille, G.: Comprehensive primary particulate organic characterization of vehicular exhaust emissions in France, Atmos. Environ., 43, 6190-6198, 2009.

Fallah Shorshani, M. F., Seigneur, C., Polo Rehn, L., Chanut, H., Pellan, Y., Jaffrezo, J. L., Charron, A., and André, M.: Atmospheric dispersion modeling near a roadway under calm meteorological conditions, Transport. Res. D, 34, 137-154, 2015.

Favez, O., El Haddad, I., Piot, C., Boréave, A., Abidi, E., Marchand, N., Jaffrezo, J.-L., Besombes, J.-L., Personnaz, M.-B., Sciare, J., Wortham, H., George, C., and D'Anna, B.: Inter- comparison of source apportionment models for the estimation of wood burning aerosols during wintertime in an Alpine city (Grenoble, France), Atmos. Chem. Phys., 10, 5295-5314, https://doi.org/10.5194/acp-10-5295-2010, 2010.

Fujita, E. M., Zielinska, B., Campbell, D. E., Arnott, W. P., Sagebiel, J. C., Mazzoleni, L., Chow, J. C., Gabele, P. A., Crews, W., Snow, R., Clark, N. N., Wayne, W. S., and Lawson, D. R.: Variations in speciated emissions from spark-ignition and compression-ignition motor vehicles in California's south Coast air basin, J. Air Waste Manag. Assoc., 57, 705-720, 2007.

Fujitani, Y., Saitoh, K., Fushimi, A., Takahashi, K., Hasegawa, S., Tanabe, K., Kobayashi, S., Furuyama, A., Hirano, S., and Takami, A.: Effect of isothermal dilution on emission factors of organic carbon and n-alkanes in the particle and gas phases of diesel exhaust, Atmos. Environ., 59, 389-397, 2012.

Gietl, J. K., Lawrence, R., Thorpe, A. J., and Harrison, R. M.: Identification of brake wear particles and derivation of a quantitative tracer for brake dust at a major road, Atmos. Environ., 44, 141146, 2010.

Gillies, J. A., Gertler, A. W., Sagebiel, J. C., and Dippel, W. A.: On-road particulate matter $\left(\mathrm{PM}_{2.5}\right.$ and $\left.\mathrm{PM}_{10}\right)$ emissions in the Sepulveda tunnel, Los Angeles, California, Environ. Sci. Technol., 35, 1054-1063, 2001.

Golly, B., Brulfert, G., Berlioux, G., Jaffrezo, J.-L., and Besombes, J.-L.: Large chemical characterisation of $\mathrm{PM}_{10}$ emitted from graphite material production: Application in source apportionment, Sci. Total Environ., 558, 634-643, 2015.

Grigoratos, T. and Martini, G.: Brake wear particle emissions: a review, Environ. Sci. Pollut. Res., 22, 2491-2504, 2015.

Hall, F.: Chapter 2: Traffic stream characteristics, in: Traffic flow theory: A state of the art report, edited by: Gartner, N., Messer, C., and Rathi, A., available at: https://www.academia.edu/ 25432198/Traffic_Flow_Theory_A_State_of_the_Art_Report (last access: March 2019), 2001.

Handler, M., Puls, C., Zbiral, J., Marr, I., Puxbaum, H., and Limbeck, A.: Size and composition of particulate emissions from motor vehicles in the Kaisermühlen-Tunnel, Vienna, Atmos. Environ., 42, 2173-2186, 2008.

Harrad, S., Hassoun, S., Callén Romero, M. S., and Harrison, R. M.: Characterization and source attribution of the semi-volatile organic content of atmospheric particles and associated vapour phase in Birmingham, UK, Atmos. Environ., 37, 4985-4991, 2003.

Harrison, R. M., Jones, A. M., Gietl, J., Yin, J., and Green, D. C.: Estimation of the contributions of brake dust, tire wear, and resuspension to nonexhaust traffic particles derived from atmospheric measurements, Environ. Sci. Technol., 46, 6523-6529, 2012.

He, L.-Y., Hu, M., Zhang, Y.-H., Huang, X.-F., Yao, T.-T.: Fine Particle Emissions from On-Road Vehicles in the Zhujiang Tunnel, China, Environ. Sci. Technol., 42, 4461-4466, https://doi.org/10.1021/es7022658, 2008.

Hueglin, C., Gehrig, R., Baltensperger Gysel, M., Monn, C., and Vonmont, H.: Chemical characterization of $\mathrm{PM}_{2.5}, \mathrm{PM}_{10}$ and coarse particles at urban near-city and rural sites in Switzerland, Atmos. Environ., 39, 637-651, 2005.

Hueglin, C., Buchmann, B., and Weber, R. O.: Long-term observation of real-world road traffic emission factors on a motorway in Switzerland, Atmos. Environ., 40, 3696-3709, 2006. 
Hulskotte, J. H. J., Roskam, G. D., and Denier van der Gon, H. A. C.: Elemental composition of current automotive braking materials and derived air emission factors, Atmos. Environ., 99, 436445,2014

Ijima, A., Sato, K., Yano, K., Tago, H., Kato, M., Kimura, H., and Furuta, N.: Particle size and composition distribution analysis of automotive brake abrasion dusts for the evaluation of antimony sources of airborne particulate matter, Atmos. Environ., 41, 4908-4919, 2007.

Jaffrezo, J. L., Calas, N., and Bouchet, M.: Carboxylic acids measurements with ionic chromatography, Atmos. Environ., 32, 2705-2708, 1998.

Jaffrezo, J.-L., Aymoz, G., Delaval, C., and Cozic, J.: Seasonal variations of the water soluble organic carbon mass fraction of aerosol in two valleys of the French Alps, Atmos. Chem. Phys., 5, 2809-2821, https://doi.org/10.5194/acp-5-2809-2005, 2005.

Ježek, I., Katrašnik, T., Westerdahl, D., and Mocnik, G.: Black carbon, particle number concentration and nitrogen oxide emission factors of random in-use vehicles measured with the onroad chasing method, Atmos. Chem. Phys., 15, 11011-11026, https://doi.org/10.5194/acp-15-11011-2015, 2015.

Johansson, C., Norman, M., and Burman, L.: Road traffic emission factors for heavy metals, Atmos. Environ., 13, 4681-4688, 2009.

Kam, W., Liacos, J. W., Schauer, J. J., Delfino, R. J., and Sioutas, C.: On-road emission factors of PM pollutants for light-duty vehicles (LDVs) based on urban street driving conditions, Atmos. Environ., 61, 378-386, 2012.

Katsoyiannis, A., Sweetman, A. J., and Jones, K. C.: PAH molecular diagnostic ratios applied to atmospheric sources: a critical evaluation using two decades of source inventory and air concentration data from the UK, Environ. Sci. Technol., 45, 8897-8906, 2011.

Kean, A. J., Littlejohn D., Ban-Weiss, G. A., Harley, R. A., Kirchstetter, T. W., and Lunden, M. M.: Trends in on-road vehicle emissions of ammonia, Atmos. Environ., 43, 1565-1570, 2009,

Keyte, I. J., Albinet, A., and Harrison, R. M.: On-road traffic emissions of polycyclic aromatic hydrocarbons and their oxy- and nitri- derivative compounds measured in road tunnel environments, Sci. Total Environ., 566-567, 1131-1142, 2016.

Kim, Y., Sartelet, K., Seigneur, C., Charron, A., Besombes, J. L., Jaffrezo, J. L., Marchand, N., and Polo, L.: Effect of measurement protocol on organic aerosol measurements of exhaust emissions from gasoline and diesel vehicles, Atmos. Environ., 140, 176-187, 2016.

Kleeman, M. J., Riddle, S. G., Robert, M. A., and Jakober, C. A.: Lubricating oil and fuel contribution to particulate matter emissions from light-duty gasoline and heavy-duty diesel vehicles, Environ. Sci. Technol., 42, 235-242, 2008.

Kukutschová, J., Roubíček, V., Malachová, K., Pavlíčková, Z., Holuša, R., Kubačková, J., Mička, V., MacCrimmon, D., and Filip, P.: Wear mechanism in automotive brake materials, wear debris and its potential environmental impact, Wear, 267, 807817,2009

Lawrence, S., Sokhi, R., and Ravindra, K.: Quantification of vehicle fleet $\mathrm{PM}_{10}$ particulate matter emission factors from exhaust and non-exhaust sources using tunnel measurement techniques, Environ. Pollut., 210, 419-428, 2016.

Liacos, J. W., Kam, W., Delfino, R. J., Schauer, J. J., and Sioutas, C.: Characterization of organic, metal and trace element $\mathrm{PM}_{2.5}$ species and derivation of freeway-based emission rates in Los Angeles, CA, Sci. Total Environ., 435-4365, 159-166, 2012.

Lough, G. C., Christensen, C. G., Schauer, J. J., Tortorelli, J., Mani, E., Lawson, D. R., Clark, N. N., and Gabele, P. A.: Development of molecular marker source profiles for emissions from on-road gasoline and diesel vehicle fleets, J. Air Waste Manage. Assoc., 57, 1190-1199, 2007.

Malig, B. J., Green, S., Basu, R., and Broadwin, R.: Coarse particles and respiratory emergency department visits in California, Am. J. Epidemiol., 178, 58-69, https://doi.org/10.1093/aje/kws451, 2013.

McDow, S. R. and Huntzicker, J. J.: Vapor adsorption artefact in the sampling of organic aerosol: face velocity effects, Atmos. Environ., 24A, 2563-2571, 1990.

Morawska, L. and Zhang, J.: Combustion sources of particles. 1. Health relevance and source signatures, Chemosphere, 49, 10451058, 2002.

Omstedt, G., Bringfelt, B., and Johansson, C.: A model for vehicleinduced non-tailpipe emissions of particles along Swedish roads, Atmos. Environ., 39, 6088-6097, 2005.

Pant, P. and Harrison, R. M.: Estimation of the contribution of road traffic emissions to particulate matter concentrations from field measurements: A review, Atmos. Environ., 77, 78-97, 2013.

Pant, P., Shi, Z., Pope, F. D., and Harrison, R. M.: Characterization of Traffic-Related Particulate Matter Emissions in a Road Tunnel in Birmingham, UK: Trace Metals and Organic Molecular Markers, Aerosol Air Qual. Res., 17, 117-130, doi:10.4209/aaqr.2016.01.0040, 2017.

Pardo, M., Shafer, M. M., Rudich, A., Schauer, J. J., and Rudich, Y.: Single exposure to near roadway particulate matter leads to confined inflammatory and defense responses: possible role of metals, Environ. Sci. Technol., 49, 8777-8785, 2015.

Perrone, M. G., Carbone, C., Faedo, D., Ferrero, L., Maggioni, A., Sangiorgi, G., and Bolzacchini, E.: Exhaust emissions of polycyclic aromatic hydrocarbons, n-alkanes and phenols from vehicles coming within different European classes, Atmos. Environ., 82, 391-400, 2014.

Phuleria, H. C., Geller, M. D., Fine, P. M., and Sioutas, C.: Sizeresolved emissions of organic tracers from light- and heavy-duty vehicles measured in a California roadway tunnel, Environ. Sci. Technol., 40, 4109-4118, 2006.

Phuleria, H. C., Sheesley, R. J., Schauer, J. J., Fine, P. M., and Sioutas, C.: Roadside measurements of size-segregated particulate organic compounds near gasoline and diesel-dominated freeways in Los Angeles, CA, Atmos. Environ., 41, 4653-4671, 2007.

Piot, C.: Polluants atmosphériques organiques particulaires en Rhône-Alpes : caractérisation chimique et sources d'émissions, $\mathrm{Ph} . \mathrm{D}$ thesis, University of Savoie-Mont Blanc, available at: https://tel.archives-ouvertes.fr/tel-00661284 (last access: March 2019), 2011.

Pio, C., Cerqueira, M., Harrison, R.., Nunes, T., Mirante, F., Alves, C., Oliveira, C., Sanchez de la Campa, A., Artínaño, B., and Matos, M.: OC/EC ratio observations in Europe : re-thinking the approach for apportionment between primary and secondary organic carbon, Atmos. Environ., 45, 6121-6132, 2011.

Pio, C., Mirante, F., Oliveira, C., Matos, M., Caseiro, A., Oliveira, C., Querol, X., Alves, C., Martins, N., Cerqueira, M., Camões, F., Silva, H., and Plana, F.: Size-segregated chemical composition 
of aerosol emissions in an urban road tunnel in Portugal, Atmos. Environ., 71, 15-25, 2013.

Platt, S. M., El Haddad, I., Pieber, S. M., Zardini, A. A., SuarezBertoa, R., Clairotte, M., Daellenbach, K. R., Huang, R.J., Slowik, J. G., Hellebust, S., Temime-Roussel, B., Marchand, N., de Gouw, J., Jimenez, J. L., Hayes, P. L., Robinson, A. L., Baltensperger, U., Astorga, C., and Prévôt, A. S. H.: Gasoline cars produce more carbonaceous particulate matter than modern filter-equipped diesel cars, Sci. Rep., 7, 4926, https://doi.org/10.1038/s41598-017-03714-9, 2017.

Polo-Rehn, L.: Caractérisation des polluants dus au transport routier: apports méthodologiques et cas d'études en Rhône Alpes, Ph.D thesis, University of Grenoble Alpes, available at: https://tel.archives-ouvertes.fr/tel-00876623 (last access: March 2019), 2013.

Poprac, P., Jomova, K., Simunkova, M., Kollar, V., Rhodes, C. J., and Valko, M.: Targeting free radicals in oxidative stress-related human diseases, Trends Pharmacol. Sci., 38, 592-607, 2017.

Pulles, T., Denier van der Gon, H., Appelman, W., and Verheul, M.: Emission factors for heavy metals from diesel and petrol used in European vehicles, Atmos. Environ., 61, 641-651, 2012.

Reche, C., Querol, X., Alastuey, A., Viana, M., Pey, J., Moreno, T., Rodríguez, S., González, Y., Fernández-Camacho, R., de la Rosa, J., Dall'Osto, M., Prévôt, A. S. H., Hueglin, C., Harrison, R. M., and Quincey, P.: New considerations for PM, Black Carbon and particle number concentration for air quality monitoring across different European cities, Atmos. Chem. Phys., 11, 6207-6227, https://doi.org/10.5194/acp-11-6207-2011, 2011.

Rogge, W. F., Hildemann, L. M., Mazurek, M. A., Cass, G. R., and Simoneit, B. R. T.: Sources of fine organic aerosol: 2 . Non-catalyst and catalyst-equipped automobiles and heavy-duty diesel trucks, Environ. Sci. Technol., 27, 636-651, 1993a.

Sanders, P. G., Xu, N., Dlaka, T. M., and Maricq, M. M.: Airborne brake wear debris: size distributions, composition, and a comparison of dynamometer and vehicle tests, Environ. Sci. Technol., 37, 4060-4069, 2003.

Schauer, J. J., Kleeman, M. J., Cass, G. R., and Simoneit, R. R. T.: Measurement of emissions from air pollution sources. 5. C1C32 organic compounds from gasoline-powered motor vehicles, Environ. Sci. Technol., 36, 1169-1180, 2002.

Shirmohammadi, F., Wang, D., Hasheminassab, S., Verma, V., Schauer, J. J., Shafer, M. M., and Sioutas, C.: Oxidative potential of on-road fine particulate matter $\left(\mathrm{PM}_{2.5}\right)$ measured on major freeways of Los Angeles, CA, and a 10-year comparison with earlier roadside studies, Atmos. Environ., 148, 102-114, 2017.

Sternbeck, J., Sjödin, Å., and Andréasson, K.: Metal emissions from road traffic and the influence of resuspension-results from two tunnel studies, Atmos. Environ., 36, 4735-4744 https://doi.org/10.1016/S1352-2310(02)00561-7, 2002.
Suarez-Bertoa, R. and Astorga, C.: Isocyanic acid and ammonia in vehicle emissions, Transport. Res. D, 49, 259-270, 2016.

Thorpe, A. and Harrison, R. M.: Sources and properties of nonexhaust particulate matter from road traffic: a review, The Sci. Total Environ., 400, 270-282, 2008.

Thorpe, A., Harrison, R. M., Boulter, P. G., and McCrae, I. S.: Estimation of particle resuspension source strength on a major London Road, Atmos. Environ., 41, 8007-8020, 2007.

Timmers, V. R. J. H. and Achten, P. A. J.: Non-exhaust PM emissions from electric vehicles, Atmos. Environ., 134, 10-17, 2016.

Tobiszewski, M. and Namieśnik, J.: PAH diagnostic ratios for the identification of pollution emission sources, Environ. Pollut., 162, 110-119, 2012.

Turpin, B. J., Saxena, P., and Andrews, E.: Measuring and simulating particulate organics in the atmosphere: problems and prospects, Atmos. Environ., 34, 2983-3013, 2000.

Varrica, D., Bardelli, F., Dongarrà, G., and Tamburo, E.: Speciation of $\mathrm{Sb}$ in airborne particulate matter, vehicle brake linings, and brake pad wear residues, Atmos. Environ., 64, 18-24, 2013.

Vecchi, R., Valli, G., Fermo, P., D’Alessandro, A., Piazzalunga, A., and Bernardoni, V.: Organic and inorganic sampling artefacts assessment, Atmos. Environ., 43, 1713-1720, 2009.

Von Uexküll, O., Skerfving, S., Doyle, R., and Braungart, M.: Antimony in brake pads - a carcinogenic component?, J. Clean. Product., 13, 19-31, 2005.

Waked, A., Favez, O., Alleman, L. Y., Piot, C., Petit, J.-E., Delaunay, T., Verlinden, E., Golly, B., Besombes, J.-L., Jaffrezo, J.L., and Leoz-Garziandia, E.: Source apportionment of $\mathrm{PM}_{10}$ in a north-western Europe regional urban background site (Lens, France) using positive matrix factorization and including primary biogenic emissions, Atmos. Chem. Phys., 14, 3325-3346, https://doi.org/10.5194/acp-14-3325-2014, 2014.

Weber, S., Uzu, G., Calas, A., Chevrier, F., Besombes, J.-L., Charron, A., Salameh, D., Ježek, I., Mocnik, G., and Jaffrezo, J.L.: An apportionment method for the oxidative potential of atmospheric particulate matter sources: application to a one-year study in Chamonix, France, Atmos. Chem. Phys., 18, 96179629, https://doi.org/10.5194/acp-18-9617-2018, 2018.

Zhang, X. L., Tao, S., Liu, W. X., Yang, Y., Zuo, Q., and Liu, S. Z.: Source diagnostics of polycyclic aromatic hydrocarbons based on species ratios: a multimedia approach, Environ. Sci. Technol., 39, 9109-9114, 2005.

Zielinska, B., Sagebiel, J., McDonald, J. D., Whitney, K., and Lawson, D. R.: Emission rates and comparative chemical composition from selected in-use diesel and gasoline-fueled vehicles, J. Air Waste Manage. Assoc., 54, 1138-1150, 2004. 